UNITED STATES DEPARTMENT OF THE INTERIOR

GEOLOGICAL SURVEY

\title{
GEOLOGY OF THE RAINIER MESA-AQUEDUCT MESA TUNNEL AREAS-- U12n TUNNEL
}

\section{By}

\section{D.L. Hoover and J.E. Magner}

\section{Open-File Report 90-623}

\author{
Prepared in conperation with the \\ Nevada Operations of fice \\ U.S. Department of Energy \\ (Interagency Agreement DE-AI08-86NV10583) \\ and the \\ Defense Nuclear Agency
}

This report is preliminary and has not been reviewed for conformity with U.S. Geological Survey editorial standards and stratigraphic nomenclature. Any use of trade names is for descriptive purposes only and does not imply endorsement by the USGS 
Copies of this Open-File Report may be purchased from

Books and Open-File Reports Section

Branch of Distribution

U.S. Geological Survey

Box 25425 Federal Center

Denver, Colorado 80225

\section{PREPAYMENT IS REQUIRED}

Price information will be published in the monthly listing

"New Publications of the Geological Survey"

\section{FOR ADDITIONAL ORDERING INFORMATION}

CALL: Commercial: (303) 236-7476

FTS: $776-7476$ 
UNITED STATES DEPARTMENT OF THE INTERIOR

GEOLOGICAL SURVEY

GEOLOGY OF THE RAINIER MESA-AQUEDUCT MESA TUNNEL AREAS-U12n TUNNEL

By

D.L. Hoover and J.E. Magner

Open-File Report 90-623 


\section{CONTENTS}

Abstract.......................................

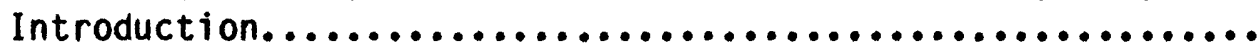

Previous investigations...........................

Stratigraphy......................................

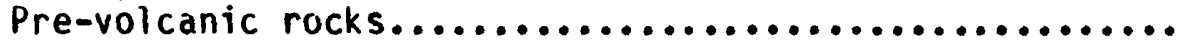

Stirling Quartzite and Wood Canyon Formation........

Ordovician to Devonian dolomite and 1 imestone........

Gold Meadows stock..............................

Volcanic rocks...................................

Lithologic terminology.......................

Bedded tuffs..............................

Calc-alkaline rocks..........................

Peralkaline rocks...........................

Ash-flow tuffs............................

Ash-fall tuffs............................

Reworked ash-fall tuffs.....................

Tuffaceous sandstones......................

Vitric rocks..............................

Zeolitized rocks...........................

Argillized rocks...........................

Silicified rocks...........................

Paleocolluvium..............................

Older tuffs...............................

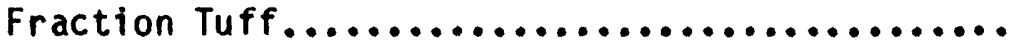

01 der bedded tuffs..........................

Redrock Valley Tuff........................

Tunnel beds..................................

Tunnel bed $1 \ldots \ldots \ldots \ldots \ldots \ldots \ldots \ldots \ldots \ldots \ldots \ldots \ldots \ldots \ldots$

Tuft of Yucca Flat.........................

Tunnel bed 2.............................

Tub Suring Member of the Belted Ranye Tuff......

Tunnel bed $3 . . \ldots \ldots \ldots \ldots \ldots \ldots \ldots \ldots \ldots \ldots \ldots \ldots \ldots \ldots$

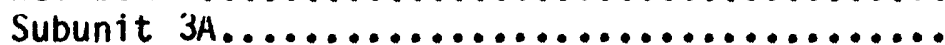

Subunit $3 B C \ldots \ldots \ldots \ldots \ldots \ldots \ldots \ldots \ldots \ldots \ldots \ldots \ldots \ldots \ldots$

Subunit 30............................

Tunnel bed $4 \ldots \ldots \ldots \ldots \ldots \ldots \ldots \ldots \ldots \ldots \ldots \ldots \ldots \ldots \ldots$

Subunit $4 A-D \ldots \ldots \ldots \ldots \ldots \ldots \ldots \ldots \ldots \ldots \ldots \ldots$

Subunit 4E...........................

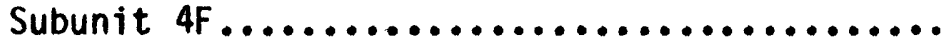

Subunit $4 G \ldots \ldots \ldots \ldots \ldots \ldots \ldots \ldots \ldots \ldots \ldots \ldots \ldots \ldots . . . \ldots$

Subunit $4 H . \ldots \ldots \ldots \ldots \ldots \ldots \ldots \ldots \ldots \ldots \ldots \ldots . \ldots \ldots$

Subunit 4 J.............................

Subunit $4 k \ldots \ldots \ldots \ldots \ldots \ldots \ldots \ldots \ldots \ldots \ldots \ldots \ldots \ldots$ 
Stratigraphy--Continued

Volcanic rocks--Continued

Tunnel beds--Continued

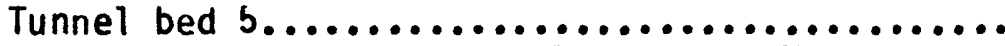

Grouse Canyon Member of the Belted Range Tuff.......

Tuffs of Area 20 and of Dead Horse Flat.............

Stockade Wash Tuff............................

Bedded tuffs of the Paintbrush Tuff................

Timber Mountain Tuff..........................

Rainier Mesa Member.........................

Bedded tuffs of the Ammonia Tanks Member........

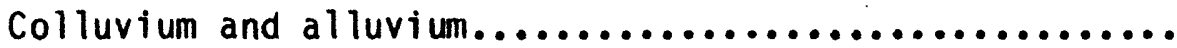

Distribution of lithologies and rock alteration............

Zeolitization..................................

Argillization...................................

Silicification..................................

Map compilation..................................

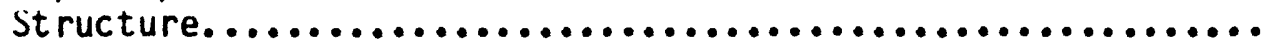

Pre-volcanic structures..........................

CP thrust fault............................

Right-lateral fault zone.......................

Gold Meadows stock.............................

Aye of $C P$ thrust fault and the right-lateral

fault zone................................

Structures in volcanic rocks.....................

Depositional folds..........................

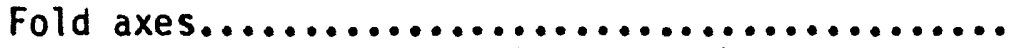

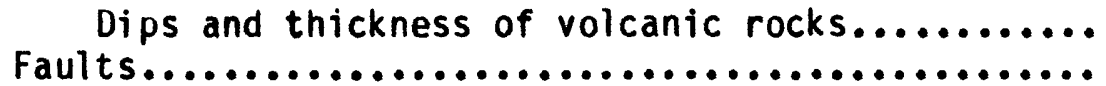

References cited. 


\section{Illustrations}

Plate 1.--Geoloyic map of the top of the pre-volcanic rocks in the U12n area..................

2.--Tunnel-level geoloyic map of the U12n tunnel complex......................

3.--Offset features of a right-lateral fault zone, Yucca Flat, Nevada Test Site.............

4.--Surface yeologic map of the U12n area............

b. - - Cross sections of the Ulin area.................

Figure 1. Index map of the Nevada Test Site................

2. Index map of Rainier Mesa and vicinity............

Page

3. Map showing distribution of quartzite and micaceous schist in drill holes in the U12n area.........

In pocket

In pocket

In pocket

In pocket

In pocket

4. Graph showing stratigraphic distribution of lithologies and rock alteration in tunnel beds $2-b$ from horizontal and vertical holes, U12n area.......

b. Graph showing stratigraphic distribution of argillized ash-fall tuff, argillized calc-alkaline ash-fall tuff, and silicified tuffaceous sandstone comparea to distribution of ash-fall tuff, calc-alkaline ash-fall tuff, and tuffaceous sandstone, respectively, from horizontal and vertical drill holes.......................

6. Cross section along centerline of Ui2n. Us main arift showing intense argillization near faults and synclinal axis in tunnel bed units

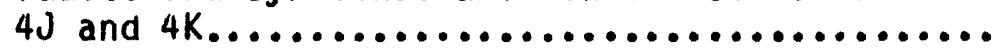

\section{TABLES}

Table 1.--Development of stratigraphic nomenclature of volcanic rocks in the Rainier Mesa area..........

2.--Stratiyraphic units in the $U 12 n$ area, Rainier Mesa, Nevada Test Site................

3.--Mineralogical differences of the Fraction Tuff, Redrock Valley Tuff, and the tuff of Yucca Flat..........................

4.--Lithology of tunnel beds $2-5$ in drill holes, U12n area..........................

b.--Argillization in tunnel beds $2-5$ in drili holes, $U 12 n$ area..........................

6.--Silicification in tunnel beds $2-5$ in arili holes, $U 12 n$ area.........................

7.--Elevation of the top of zeolitization in the U12n area............................

8.--Elevation of stratigraphic units in the UE $12 n \# 6$ and RME-1 drill holes, U12n area........

y.--Comparison of total thickness and percent of reworked ash-fall tuff and tutfaceous sandstone in stratigraphic units, UEI2n\#1 and UE12n\#3.................................. 


\title{
GEOLOGY OF THE RAINIER MESA-AQUEDUCT MESA TUMNEL AREAS-- U12n TUNHEL
}

\author{
By \\ D.L. Hoover and J.E. Magner
}

\section{ABSTRACT}

The U12n tunnel area is located beneath Rainier Mesa on the Nevada Test Site, Nye County, Nevada. Stratiyraphic units in the U12n area include Precambrian and Cambrian quartzite, Ordovician to Devonian dolomite and limestone, Cretaceous quartz monzonite, $2 b$ Miocene and Pliocene volcanic rock units, and Quaternary colluvium and alluvium. Volcanic rocks in drill holes are classified into two chemical yroups: calc-alkaline and peralkaline; four depositional processes: ash-fall tuff, reworked ash-fall tuff, tuffaceous sandstone, and ash-flow tuff; and four alteration types: vitric, zeolitized, aryillized, and silicified. Alteration of the volcanic rocks to predominantiy zeolites, clay minerals, or silica is related to both stratigraphy and structure.

Pre-volcanic structures are the CP thrust fault, a right-lateral fault zone that can be projected into the U12n area, and the Gold Meadows stock; Tertiary structures are depositional folds and predominantly normal faults. The right-lateral fault zone may have provided pre-existing planes of weakness during Tertiary deformation that resulted in west-northwest to northwest normal faults in the U12n area in contrast to north-south to north-northeast faults north and south of the U12n area. Normal faults at tunnel level have displacements that range from less than 3 to $125 \mathrm{ft}$ or more. The Tertiary volcanic rocks were deposited on a pre-Tertiary, steep-sided drainage system and formed depositional folds. The Rainier Mesa depositional syncline is the major structure in the UIZn area in addition to the normal faults. Drill-hole data inaicate that the axis of syncline in the volcanic rocks parallels the contact between quartzite in the upper plate and dolomite and limestone in the lower plate of the $\mathrm{CP}$ thrust fault.

\section{INTROUUCTION}

Rainier and Ayueduct Mesas have been the location of most of the underground nuclear tests in tunnels at the Nevada Test Site (NTS), Nye County, Nevada. The area is about 75 miles ${ }^{1}$ west-northwest of Las Vegas and about $3 b$ miles north-northwest of Mercury, Nevada (fig. 1). The first underground nuclear test was conducted in the U12b tunnel on Rainier Mesa in 19b7. Between 1970 and 1985, nuclear testing has been conducted in three tunnels, U12e, U12n, and U12t (tig. 2).

Between 1957 and 1981, the U.S. Geological Survey conducted most of the yeoloyical and geophysical investigations in the tunnels on Rainier and Aqueduct Mesas. Much of the data from these investigations was reported in administrative reports and memoranda to the National Laboratories and the Department of Defense, who were conducting the underyround nuclear testing in the tunnels.

\footnotetext{
1Numerical data from source documents and maps used to compile this report were all measured in the English system. The English system has been retained in this report to eliminate the task of conversion to the metric system and to prevent errors that might be caused by conversion.
} 


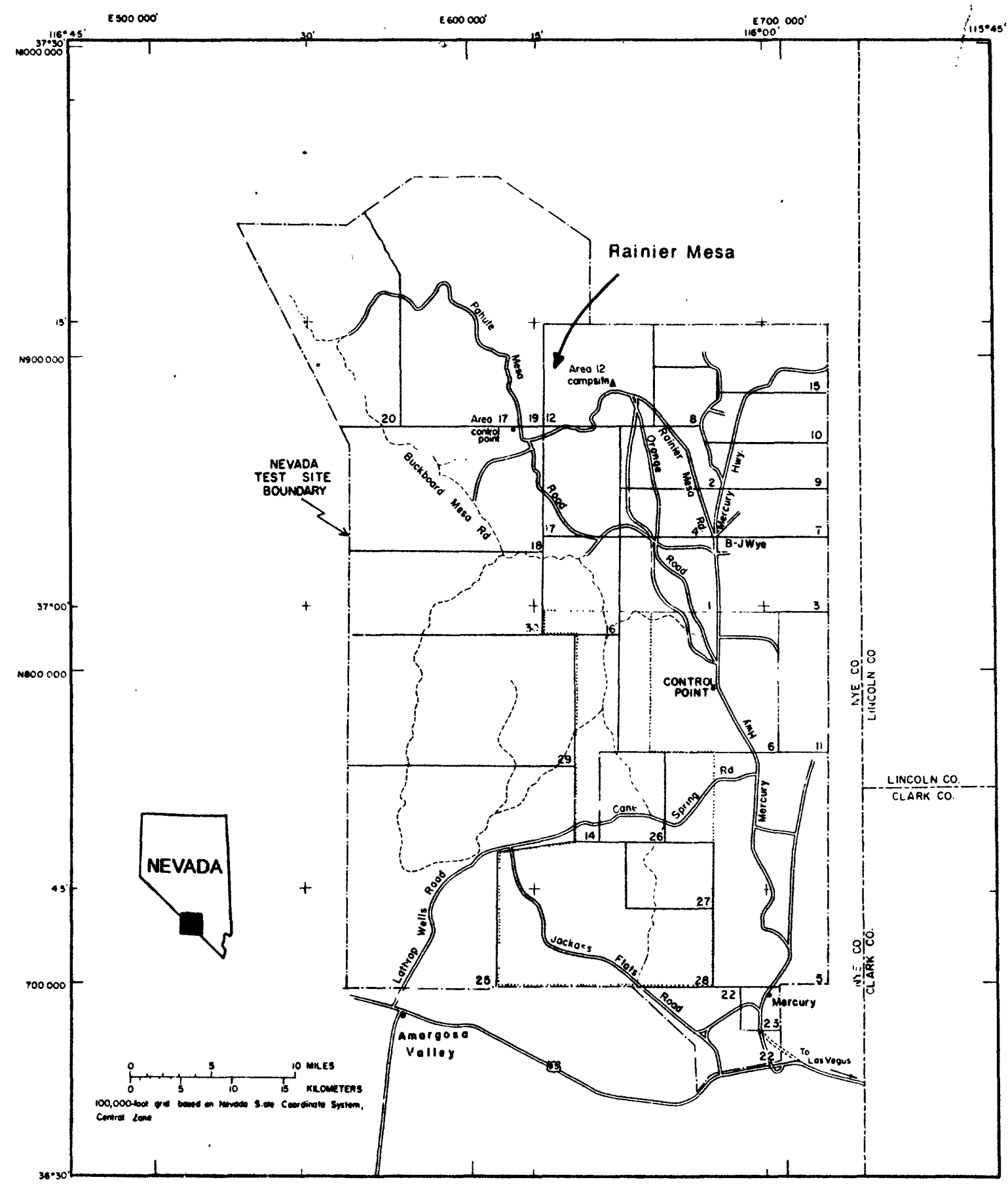

Figure 1.--Index map of the Nevada Test Site. 


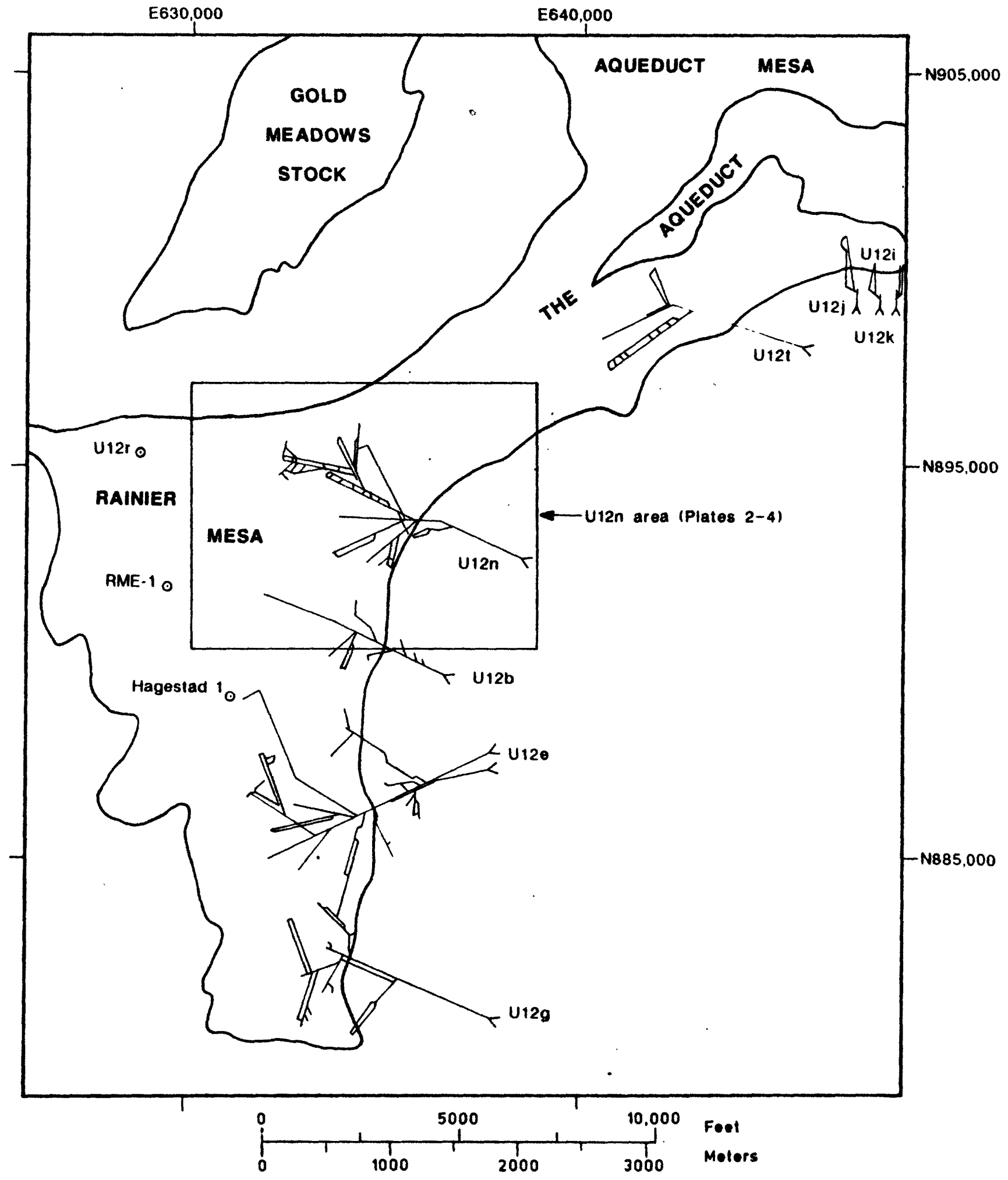

Figure 2.--Index map of Rainier Mesa and vicinity. 
The purpose of this report is to summarize and interpret the yeology of the UI2n tunnel area from published reports and data in the files of the U.S. Geological Survey. Some data are derived from unpublished reports by yeoloyists of Fenix \& Scisson of Nevada on drifts and drill holes constructed between 1981 and 1985 that were transmitted to the U.S. Geoloyical Survey for the purpose of containment evaluation. Stratigraphic contacts in cores were checked or revised where strip loys of litholoyies in drill holes indicated contacts miyht be in error. The report emphasizes stratigraphy and structure. Alteration of the volcanic rocks to zeolites and clay are discussed in the context of stratigraphy and structure, but their effects on tunnel construction, containment of nuclear tests, and physical and dynamic properties of the rocks are not discussed because of insufficient data in the files of the U.S. Geological Survey.

The UIZn tunnel portal is located on the east side of Rainier Mesa at an elevation of $6,023 \mathrm{ft}$ at Nevada State coordinates N. $892,667 \mathrm{ft}$ and E. $638,64 \mathrm{~b} \mathrm{ft}$ (fig. 2). The access adit and main drifts for nuclear experiments have a total length of more than $30,000 \mathrm{ft}$. Drifts parallel to the main drifts, cross cuts, and side drifts total more than 16,000 ft. Horizontal and vertical exploratory drill holes that were entirely cored total more than 42,000 ft. Additional, short horizontal and angled drill holes for yeophysical and yeological data and vertical holes for instrumentation total more than $16,000 \mathrm{ft}$.

The U12n drifts have been driven into bedded tuffs of Tertiary age beneath Rainier Mesa. The mesa is steep-sided, roughly trapezoidal, and capped by densely welded tuff. The top of the mesa above the U12n tunnel ranyes in elevation from about $7030 \mathrm{ft}$ to $7 b 00 \mathrm{ft}$ or $1007 \mathrm{ft}$ to $1477 \mathrm{ft}$ above the tunnel portal. Above the $U 12 n$ area, surface drainage is to the northeast along the axis of a depositional syncline in densely welded tuff.

In the U12n area, older volcanic rocks were deposited in a southwestdraining valley and its tributaries and form a depositional syncline. Ashflow tuffs at the surface were deposited in a valley that drains northeast. At the south end of Kainier Mesa, the western flank of the syncline may have been removed by erosion. Northeast of the U12n area, the Aqueduct and Aqueduct Mesa are also depositional synclines (Gibbons and others, 1963).

Structures adjacent to Rainier Mesa that may have influenced the depositional and structural history of the mesa include:

1. The complex graben that forms Yucca Flat about 3 mi east of Rainier Mesa.

2. The Timber Mountain caldera, the walls of which are about 1 mi southwest of the southwestern corner of the mesa.

3. The Silent Canyon caldera, the walls of which are 1-3 mi west of the mesa.

4. The Gold Meadows stock that intrudes Precambrian and Cambrian quártzite at the north edge of the mesa.

The two calderas were sources for most of the volcanic rocks beneath Rainier and Aqueduct Mesas. 


\section{Previous Investigations}

The U.S. Geoloyical Survey began investigations of the Nevada Test Site in 1951. Stratigraphic nomenclature of the Rainier Mesa area has been developed as investiyations of other NTS areas added to the knowledge of the volcanic stratigraphy. Development of the present volcanic stratigraphy (table 1) is only outlined in this report.

Johnson and Hibbard (19b7) mapped the volcanic rocks of NTS, including Rainier Mesa, as the Oak Suring Formation. Hansen and Lemke (1958) mapued parts of Rainier Mesa south and east of the U12n tunnel area and divided the Uak Spring Formation into eight members. On Rainier Mesa, volcanic rocks below the lower part of the Grouse Canyon were divided into tunnel beds 1-4. Hinrichs and Orkild (1961) placed the tunnel beds in the lower member of the Oak Spring Formation and identified the Tub Spring Member as a separate stratigraphic unit. Poole and Mckeown (1962) raised the Oak Spring Formation to the rank of group and divided it into the Piapi Canyon and the Indian Trail Formations. The Piapi Canyon Formation included all units above the Grouse Canyon Member. The Indian Trail Formation included the Grouse Canyon Member, the Tub Spring Member, and an informal unit, the lower member (Gibbons and others, 1963). The lower member included tunnel beds 1-4 and other informal units.

Recognition of the similarity in chemistry and source of the peralkaline ash-flow tuffs of the Grouse Canyon and the Tub Spring resulted in the redefinition of these members as the Belted Range Tuff (Sargent and others, 1965). The ash-fall tuffs of the lower member of the Grouse Canyon were included as informal units of the Belted Range Tuff. In the Rainier Mesa area, these ash-fall tuffs have been mapped as tunnel bed 5 since the definition of the Belted Range Tuff. At the same time, the Piapi Canyon Formation was redefined as the Paintbrush Tuff and the Ammonia Tanks and Rainier Mesa Members of the Timber Mountain Tuff (Orkild, 1965). Dixon and others (1976) abandoned the name, Indian. Trail Formation, defined the Crater Flat Tuff, Redrock Valley Tuff, and Fraction Tuff, and relegated all other volcanic rocks below the Grouse Canyon Ranye Tuff except these tuffs and the Tub Spring Member to informal units that include tunnel beds $1-b$ in the Rainier Mesa area. The ash-flow tutf formerly identified as the Crater Flat Tuff in the Rainier Mesa area has been demonstrated to differ petroyraphically from the Crater Flat Tuff at its type locality. This tuff has been informally named the tuff of Yucca Flat in the Rainier Mesa-Yucca Flat area (Carr and others, 1984). Stratigraphic units in vertical arill holes are summarized by Maldonado and others (197y).

Depositional folds and the northwest trend of faults in the U12n area are apparent on the Kainier Mesa geologic map (Gibbons and others, 1963). Carr (1974) noted the northwest-trending right-lateral fault zone that projects through the U12n area and related this and other fault zones to the Walker Lane and reyional stress patterns. The structural geology of the U12n.02, U12n.03, and U12n.1U drifts was describea in separate reports (Eye, Uanilchik, and Feazel, 1980; Eye, Carroll, and others, 1980; U.S. Geological Survey, 1979). Healey and Miller (1963) defined the configuration of the Gold Meadows stock on the basis of gravity data. Snyder (1977) mapped the Gold Meadows stock in detail. The CP thrust fault beneath the U12n area is named for an outlier of the upper plate in the CP Hills south of Rainier Mesa (Barnes and Poole, 1968). 


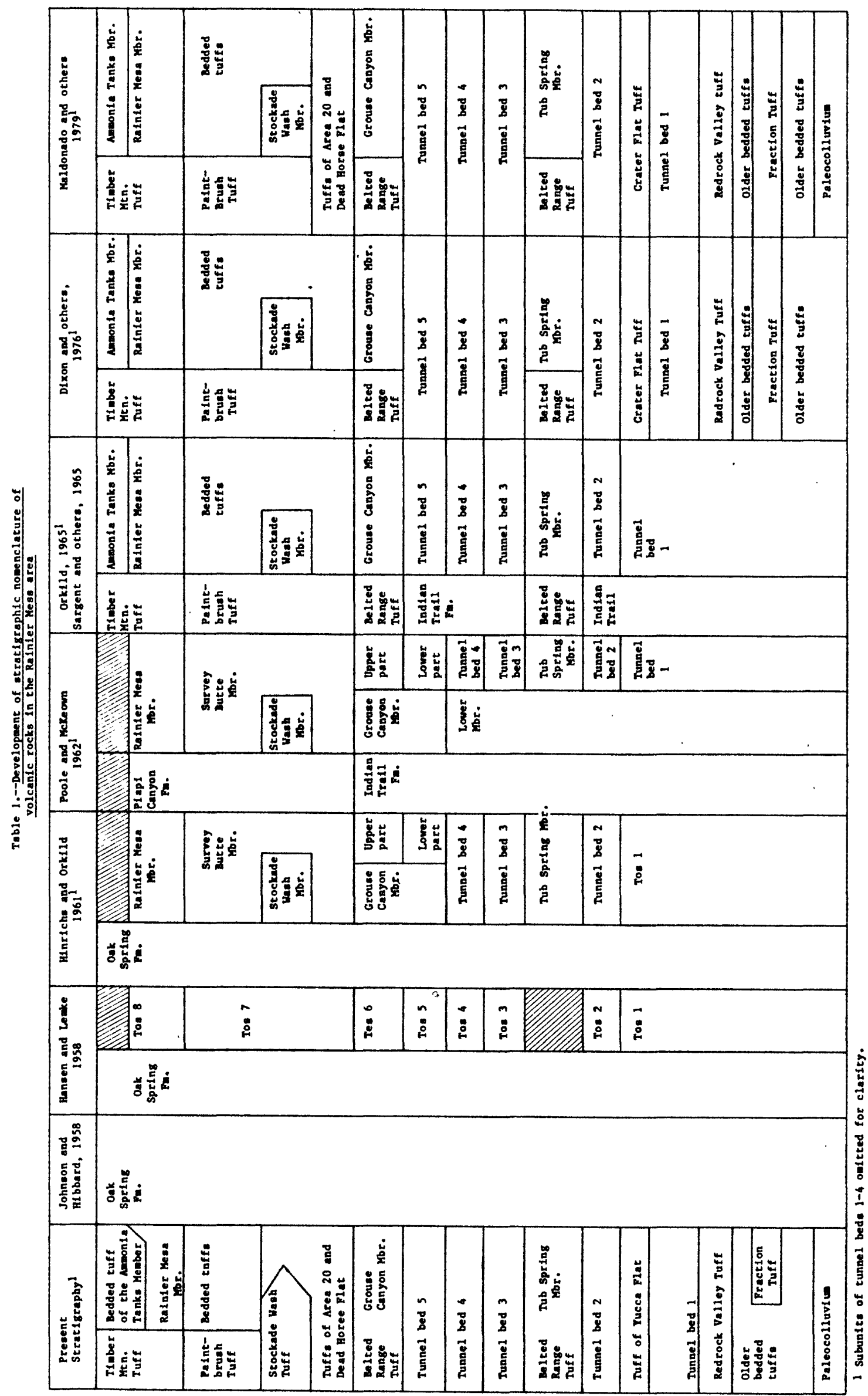


Investigations have been related of zeolites, clay minerals, and silica mostly to mineral or yround-water chemistry in administrative reports and on arill-hole strip logs. The occurrence of abundant clay in the U1'2n.03 drift was related to faults and the axis of the Rainier Mesa syncline (Ege, Carroll, and others, 1980). The relationship of zeolites and other alteration products to stratigraphy and lithology was part of an investiyation of the genesis of zeolites in the NTS area (Hoover, 1968).

\section{STRATIGRAPHY}

Rocks within the U12n tunnel area include Precambrian to Cambrian quartzite and schist, Ordovician to Vevonian dolomite and limestone, Cretaceous quartz monzonite, Miocene and Pliocene ash-flow tuffs, ash-fall tuffs, and tuffaceous sediments, and Quaternary alluvium and colluvium (table 2). The Precambrian and Paleozoic sedimentary rocks were highly deformed prior to intrusion of the Cretaceous Gold Meadows stock of quartz monzonite. Erosion of the sedimentary rocks and the quartz monzonite stock left a surface of high relief on which the volcanic rocks were deposited. Stratigraphic units in the basal part of the volcanic rocks are deeply eroded, but younyer volcanic rocks contain only local unconformities in the $U 12 n$ area.

\section{Pre-volcanic Rocks}

\section{Stirling Quartzite and Wood Canyon Formation}

The Stirliny Quartzite of Precambrian aye and the Wood Canyon Formation of Precambrian(?) and Cambrian age crop out north of the U12n area. The outcrops are on the south and east sides of the Gold Meadows stock which intrudes these formations (Gibbons and others, 1963). Quartzite, schist, and micaceous siltstone of the two formations have been penetrated in the UE12n\#2, \#3, \#8, \#y, and \#10 drill holes (pl. 1), the Rainier Mesa Exploratory \#1 (RME1) (fig. 2) drill hole, the Hagestad \#1 drill hole, and drill holes in tunnels around the U12n.10 working point (WP) (pl. 1). All drill holes referred to are in the U12n area (fig. 2, pl. 3) unless otherwise noted.

Both formations are named for locations in the Spring Mountains (Nolan, 1929). Although the two formations differ in the content of micaceous rocks and color, parts of each formation resemble the other. The Stirling Quartzite is mostly dark-reddish-purple and dark-brown to pale-red and pinkish-gray micaceous quartzite in the lower part, grayish-red micaceous siltstone and pinkish-yray quartzite in the middle part and micaceous siltstone grading upward to light-gray quartzite in the upper part. The Wood Canyon Formation consists of yellowish-yray and yrayish-orange micaceous siltstone and shale with interbedded quartzite in the lower part, grayish-red quartzite in the middle part and liyht-yray quartzite and dusky-yellow to light-olive very micaceous siltstone and quartzite in the upper part (Harley Barnes and others, written commun., 1963). This similarity and alteration of the rocks near the Gold Meadows stock led to mapping of the two formations as one unit just north of Rainier Mesa (Gibbons and others, 1963). 
Table 2.--Stratigraphic units in the U12n area, Rainier Mesa, Nevada Test STte

\begin{tabular}{|c|c|c|c|c|c|}
\hline Era & System & Series & Stratigraphic unit & Map $_{\text {symbol }}$ & $\begin{array}{c}\text { Age }^{l} \\
\left(\mathrm{~m}_{.} y_{.}\right)\end{array}$ \\
\hline \multirow{4}{*}{ CENOZOIC } & Quaternary & & Alluvium and colluvium & Qac & \\
\hline & Tertiary & Pliocene & $\begin{array}{l}\text { Timber Mountain Tuff } \\
\text { Bedded tuffs of the Ammonia Tanks Member } \\
\text { Rainier Mesa Member }\end{array}$ & $\begin{array}{l}\text { Tmrab } \\
\text { Tmr }\end{array}$ & 11.1 \\
\hline & & Miocene & $\begin{array}{l}\text { Paintbrush Tuff } \\
\text { Bedded tuffs } \\
\text { Stockade Wash Tuff } \\
\text { Tuffs of Area } 20 \text { and Dead Horse Flat } \\
\text { Belted Range Tuff } \\
\text { Grouse Canyon Member } \\
\text { Tunnel bed } 5 \\
\text { Tunnel bed } 4 \\
\text { Subunit } 4 \mathrm{~K} \\
\text { Subunit } 4 \mathrm{~J} \\
\text { Subunit } 4 \mathrm{H} \\
\text { Subunit } 4 \mathrm{G} \\
\text { Subunit } 4 \mathrm{~F} \\
\text { Subunit } 4 \mathrm{E} \\
\text { Subunit } 4 \mathrm{~A}-\mathrm{D} \\
\text { Tunnel bed } 3 \\
\text { Subunit } 30 \\
\text { Subunit } 3 \mathrm{BC} \\
\text { Subunit } 3 \mathrm{~A} \\
\text { Belted Range Tuff } \\
\text { Tub Spring Member } \\
\text { Tunnel bed } 2 \\
\text { Tuff of Yucca Flat } \\
\text { Tunnel bed } 1 \\
\text { Redrock Valley Tuff } \\
\text { Older tuffs } \\
\text { Fraction Tuff } \\
\text { Bedded tuffs }\end{array}$ & $\begin{array}{l}\text { Tpb } \\
\text { Tsw } \\
\text { Trdb } \\
\text { Tbg } \\
\text { Tt5 } \\
\text { Tt 4K } \\
\text { Tt44J } \\
\text { Tt4H } \\
\text { Tt4G } \\
\text { Tt4F } \\
\text { Tt4E } \\
\text { Tt 4A-D } \\
\text { Tt 3D } \\
\text { Tt 3BC } \\
\text { Tt 3A } \\
\text { Tbt } \\
\text { Tt2 } \\
\text { Tyf } \\
\text { Tt 1 } \\
\text { Trv } \\
\text { Tf } \\
\text { Tot }\end{array}$ & $\begin{array}{l}14.8-15.7 \\
15.7 \\
16-18\end{array}$ \\
\hline & & Miocene(?) & Paleocolluvium & Tc & \\
\hline MESOZOIC & Cretaceous & & Gold Meadows stock & $\mathrm{Kqm}$ & 93.6 \\
\hline \multirow[t]{2}{*}{ PALEOZOIC } & $\begin{array}{l}\text { Devonian } \\
\text { Silurian } \\
\text { Ordovician }\end{array}$ & & Dolomite and limestone & DSO1 & \\
\hline & Cambrian & & Wood Canyon Formation & & \\
\hline \multicolumn{3}{|c|}{ PRECAMBRIAN } & Stirling Quartzite & & \\
\hline
\end{tabular}

\footnotetext{
${ }^{1}$ Sources of age dates are listed in text.
} 
Sections of the Stirling Quartzite and the Wood Canyon Formation penetrated in drill holes in the U12n area are too short to identify the stratigraphic unit. The distribution of quartzite and micaceous schist in drill holes in the northern part of the U12n area (fig. 3) indicates that identification of either formation is uncertain in short drill hole penetrations. Quartzite in the U12n area commonly lacks the reddish to brownish color typical of the Stirling Uuartzite. Proximity of the Gold Meadows stock, presence of yuartz monzonite in the UE12n\#10 and RME-1 drill holes, and presence of yarnet, pyrite, and maynetite in these holes indicate that the color of the Stirling Quartzite may be bleached by contact metamorphism. Presence of schist, rather than micaceous siltstone found in other areas, may also inaicate contact metamorphism. Because distinction of the two formations is uncertain in the limited sections in drill holes, these rocks are referred to in this report as undifferentlated Stirling Quartzite and Wood Canyon Formation.

\section{Ordovician to Devonian Dolonite and Limestone}

Ordovician to Devonian dolomite crops out just east of Rainier Mesa. The northernmost outcrop is about $2000 \mathrm{ft}$ east of the $U 12 \mathrm{n}$ tunnel portal (Gibbons, and others, 1963). The dolomite in outcrops is light to dark gray with some mottled grayish-red beds, finely crystalline, and very thin bedded to massive (Gibbons and others, 1963). In the U12n area, the U12b.07-2 drill hole penetrated $29 \mathrm{bt}$ of dolomite that underlies the volcanic rocks. The dolomite in this drill hole is light to dark gray, fine to medium crystalline, and indistinctly bedded. Dolomite and limestone have been penetrated only in holes southeast and east of synclinal dxis in the U12n area and areas to the north. Subcrops of dolomite and limestone beneath volcanic rocks have been found only in drill holes in the southern part of the U12n area and further south.

Lack of fossils makes the age of the dolomite uncertain. In the Ranger Mountains southeast of NTS, dolomite that was correlated by lithology to the Rainier Mesa outcrous contains Middle Ordovician to Silurian fossils. Dolomite of the Nevada Formation of Middle Devonian age is present as fault blocks in Rainier Mesa outcrops (Harley Barnes and others, U.S. Geoloyical Survey, written commun., 1963).

\section{Gold Meadows Stock}

A quartz monzonite stock of Cretaceous age crops out in Gold Meadows about $2500 \mathrm{ft}$ north of the edye of Rainier Mesa (fig. 2). The quartz monzonite intrudes the Stirling Quartzite and Wood Canyon Formation that dip $22^{\circ}$ to $65^{\circ}$ into the quartz monzonite outcrop (Gibbons and others, 1963). The UE12n\#10 drill hole penetrated $27 \mathrm{ft}$ of quartz monzonite beneath the volcanic rocks (Maldonado and others, 1979), and $62 \mathrm{ft}$ of the Stirling Quartzite and Wood Canyon Formation beneath the quartz monzonite. Pre-volcanic rocks were not penetrated in the UE12n\#11 drill hole, but paleocolluvium at the bottom, which overlies pre-volcanic rocks in nearby drill holes, contains both quartz monzonite and quartzite clasts. In the RME-1 drill hole about $66 \mathrm{ft}$ of quartz monzonite overlie $121 \mathrm{ft}$ of quartzite in the bottom of the hole. The quartzite contains pyrite and is intruded by pegmatite, aplite, and granite at $3,722,3,762$, and approximately $3,765 \mathrm{ft}$, respectively (V.C. Cole, written commun., 199u). About $1,400 \mathrm{ft}$ west of the $U 12 \mathrm{n}$ area and about $3,0 U 0 \mathrm{ft}$ north-northwest of the RME-1 drill hole, the U12r drill hole penetrated $540 \mathrm{ft}$ of quartz monzonite beneath the volcanic rocks. 


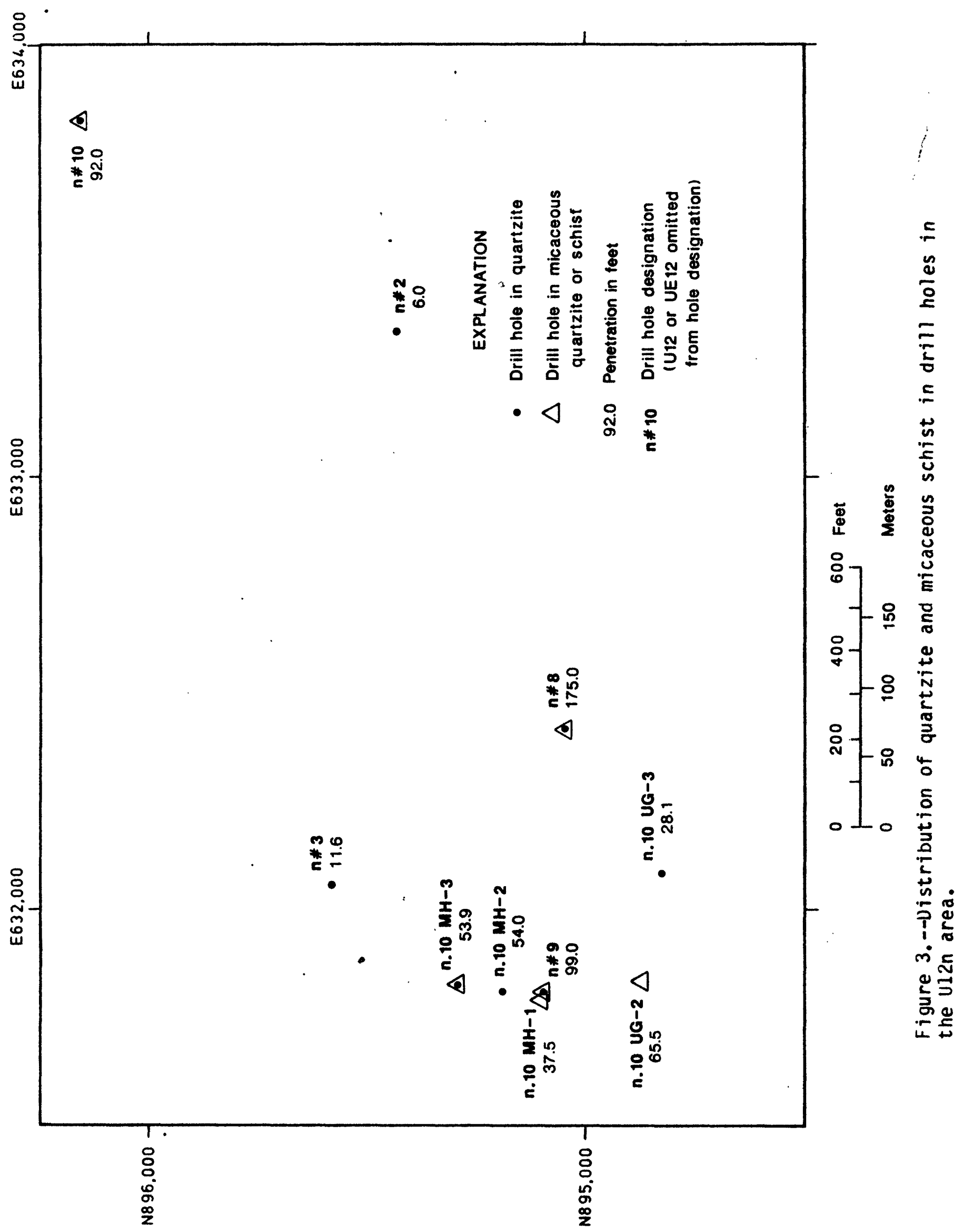


The quartz monzonite contains quartz (18.2-32.8 percent), alkali feldspar (19.5-47.8 percent), plagioclase (15.5-50.5 percent), biotite (0.8-6.6 percent), and accessory apatite, sphene, and opaque minerals (Snyder, 1977). Biotite from the quartz monzonite is 93.6 m.y. old (Naeser and Maldonado, 1981).

Gravity data indicate a steep slope on the quartz monzonite beneath the northern edye of Rainier Mesa (Healey and Miller, 1963). Pegmatite dikes in quartzite and schist that were penetrated in the UEl $2 \mathrm{n} .10$ drill hole indicate that the quartz monzonite is north of the mesa eaye at tunnel level ( $\mathrm{pl}$. 3 ) in the U12n area.

\section{Volcanic Rocks}

Volcanic rocks in the Rainier Mesa area include ash-flow and ash-fall tutts, reworked ash-fall tuffs, and tuffaceous sandstones. Most of the volcanic rocks originated in the Timber Mountain and Silent Canyon volcanic centers, but the oriyin of some tuffs has not been identified. Reworked ash-fall tuffs and tuftaceous sandstones have been derived locally from ash-fall tutfs.

The volcanic rocks are divided into two petroloyic yroups: calc-alkaline and peralkaline. Difterent classification systems have been used to emphasize differences in calc-alkaline rocks and to denote the uniqueness of peralkaline rocks (Byers and others, 1976). Calc-alkaline ash-flow tuffs older than the Paintbrush Tuff are normal calc-alkalic rhyolites; ash-flow tuffs of the Paintbrush Tuff and younger rocks are alkali-calcic and range from quartz latite to rhyolite. Peralkaline rocks are comenditic ash-flow and ash-fall tutfs in the Rainier Mesa area.

The volcanic rocks in the U12n area were deposited in a southwesttrending valley eroded into the pre-volcanic rocks. The paleovalley has a slope of about $14^{\circ}$ on the northwest side and about $7^{\circ}$ on the southeast side. These paleoslopes are reflected in the dips of the volcanic rocks.

The stratigraphic units in the $U 12 n$ area are listed in table 2. Below tunnel bed 2, some stratigraphic units are not present everywhere because of erosion or nondeposition. Tunnel bed 2 and younger ash-fall tuffs and tuffaceous sediments are continuous in the U12n area, but the ash-flow tuffs of the Tub Spring and Grouse Canyon Members of the Belted Ranye Tutf are limited to areas on Rainier Mesa that were topoyraphically low during their deposition.

\section{Litholoyic Terminology}

With tew exceptions, the texture and lithology of individual beds are repeated in two or more stratigraphic units. Similarity of petroloyy and of depositional processes and a lack of siynificant. erosion of most of the volcanic rocks have resulted in visual similarities that are repeated throughout the bedded tuffs. Only ash-flow tuffs can be stratigraphically identified with certainty in hand specimen. 
The need for positive stratiyraphic identification has led to litholoyic descriptions that are based on visual characteristics. Petrographic investigations and chemical analyses elsewhere on the NTS coincide with similarities or differences in visual characteristics, but stratigraphic identification in the bedded tuffs of Rainier mesa is based mostly on characteristics of a sequence of beds rather than specific characteristics of one bed or one interval.

To identify stratigraphic units, individual beds are mapped or logged first on the basis of two chemical types--calc-alkaline and peralkaline; and second, on the basis of depositional process--ash-flow tuff, ash-fall tuff, reworked ash-fall tuff, and tuffaceous sandstone. The type of alteration (or its absence) is noted as vitric, zeolitized, argillized, or silicified. The visual characteristics used to identify the chemical types, depositional process, and type of alteration are described below.

Color alone can not be used to identify volcanic stratigraphic units, but color may reduce the number of possibilities. Vitric and zeolitized rocks of the same tunnel bed subunit usually differ yreatly in color. Zeolitized peralkaline rocks are usually some shade of yellow, but may also be shades of pink, white, or red. Aryillized rocks are often a dark shade of red, but also may be brown, yellow or white to light shades of gray. Stratigraphic units may also differ in color from one part of Rainier Mesa to another even though the clay or zeolite content does not chanye siynificantly. Paleo-weathering zones may be lighter or darker in color than the unweathered subunit. In short, color may be useful as a yuide within individual tunnel areas, but other characteristics are usually needed to identify a stratigraphic unit.

\section{Bedded tuffs}

Subunits of the tunnel beds contain varying amounts of ash-fall tuff, reworked ash-fall tuff, and tuffaceous sandstones that are collectively referred to as beaded tuffs. Although bedded tuffs, as defined here, do not include ash-flow tuffs, some massive ash-fall tuffs of the tunnel beds may be nonwelded ash-flow tuffs. The relatively uniform character and lack of bedding in subunits $3 \mathrm{~A}, 3 \mathrm{D}$, and $4 \mathrm{~J}$ sugyest that these stratigraphic units may be nonwelded ash-flow tuffs. Welding of these subunits has not been seen in the U12n tunnel area, but has been reported in the U12t tunnel area (D.R. Townsend, Fenix \& Scisson of Nevada, oral commun., 1986).

\section{Calc-alkaline rocks}

Calc-alkaline bedded tuffs vary in color-white, very pale gray, and pale orangish yellow, or brownish gray. Moderate- to dark-reddish or brownish hues are common, but shades of yellow are less common and green is uncommon. Pinkish hues are usually present only in very fine grained rocks. Pumice usually comprises less than 10 percent of ash-fall and reworked ash-fall tuffs, but in a few beas, pumice may be as much as 40 percent. Phenocryst content may range from less than 1 percent to commonly $b$ to 10 percent. Lithic trayments usually comprise much less than 5 percent, are usually scattered throughout a bed, and are usually less than 2 inches in diameter. Only subunit $4 E$ contains more or laryer lithic fragments. The volume of reworked ash-fall tutfs and tuffaceous sandstones may equal or exceed ash-fall tuffs in some stratigraphic units. Tuffaceous sandstones are usually less than 10 in thick and occur in tunnel beds 1-4 and the bedded tuff of the Paintbrush Tuff. 


\section{Peralkaline rocks}

Altered peralkaline rocks range from pale yellowish gray and pale orange pink to mostly yrayish yellow, yreenish yellow, and yellowish green. Reddish or brownish hues are scarce except in ash-flow tuffs. Vitric peralkaline tuffs are medium to dark yray in contrast to vitric calc-alkaline tuffs that are mostly white to light yray or pale brown. Pumice usually comprises a major part of the ash-fall and reworked ash-fall tuffs. Phenocrysts usually comprise less than 2 percent of individual beds and generally are smaller than in calc-alkal ine tufts. Lithic frayments commonly comprise $b$ to 10 percent of individual beds, are sometimes concentrated at or near the base of a section of mostly peralkaline tuff, and are often 1-4 inches in diameter in ash-fall tuffs. The volume of ash-fall tuffs is much greater than that of reworked ash-tall tuff and tuffaceous sandstones. Tuffaceous sandstones are usually less than 4 in thick and usually occur only in the uppermost subunit of tunnel bed 4 and in tunnel bed 5 .

\section{Ash-flow tuffs}

Partly to densely welded tuffs can be recognized by flattened pumice and finely crystalline quartz and feldspar that was formed by devitrification during cooling. Slightly welded to nonwelded tuffs that remained vitric after cooling and were later altered to zeolites, clay, or silica can be mistaken for ash-fall tuff where such ash-flow tuffs are less than 10 feet thick. uniformity of texture, mineralogy, and distribution of lithic fragments throughout a bed, coupled with the approximate stratigraphic position, usually serve to distinguish ash-flow from ash-fall tuffs.

\section{Ash-fall tuffs}

Ash-fall tuffs are poorly sorted, but are usually uniform in texture. Color sometimes varies from light to dark or dark to light between the bottom and top of a bed. Pumice is usually elongated with a ratio of thickness to length of 1:2 or more. Pumice may have slightly rounded ends, but wellrounded pumice is rare. Pumice and lithic frayments commonly have a maximum dimension yreater than $1 \mathrm{in}$. and are treyuently greater than 2 in. Pumice and lithic frayments are usually scattered throughout a bed.

In some intervals of peralkaline ash-fall tuffs, basal beds may have a greater amount of lithic fragments at or near the bottom of the bed. Pumice is often aryillized in a zeolitized matrix and may be a contrasting color. Reddish or brownish hues are more common in ash-fall tuffs than in reworked ash-fall-tuffs or tuffaceous sandstones.

\section{Reworked ash-fall tuffs}

Reworked ash-fall tuffs are derived from ash-fall tuffs by local sheetwash, or wind transportation. They may be gradational upward from ashfall tuffs, or where they have been transported for a sufficient distance, may be bounded by bedding planes. Reworked ash-fall tuffs are poorly to moderately sorted, but the size range of pumice and lithic fragments is usually smaller than in ash-fall tutfs. Pumice may be either argillized or zeolitized in a zeolitized matrix. Reworked ash-fall tuffs often have a "dirty" appearance that becomes recognizable only after comparison of reworked ash-fall tuffs with their ash-fall tuff equivalents. The "dirty" appearance may be caused by incorporation of oryanic matter, soil, or eolian dust. 
Tuffaceous sandstones are the result of wind or water transportation far enough to reduce the range of particle size to mostly or all sand sizes or smaller. Tuffaceous sandstones range from well-sorted sandstones comprised entirely of glass shards or altered shards to sandstones that may contain as much as 10 percent pumice or lithic frayments. Some "sandstones" may actually be ash-fall tuffs because alteration usually destroys macroscopic evidence of well-sorted, fine-grained ash-fall tuffs. Most sandstones are pale shades of yray, pink, or oranye. Pumice in sanastones is usually white or a lighter shade than the matrix. Many sandstones are sillicified. Tuffaceous sandstones are rarely more than 15 in thick and are usually less than 10 in thick.

\section{Vitric rocks}

Vitric rocks preserve the original glass of shards and pumice, but lenses and individual beds within a vitric interval may be completely altered to zeolites. Conversely, a few zeolitized beds may contain vitric pumice or patches of vitric shards. Vitric rocks usually lack the coherence of zeolitized rocks, but some nonwelded ash-flow tuffs may be slightly indurated. Most vitric rocks are white, liyht to medium gray, or pale brown.

\section{Zeolitized rocks}

Zeolitized rocks are the result of alteration of vitric rocks by ground water (Hoover, 1968). Zeolite content usually ranges from 10 to 60 percent. Silica, as cristobalite or quartz, clay minerals, and feldspar are formed with the zeolites. Zeolitized rocks typically have a chalky appearance. Color ranges from pale shades of gray to moderate red or brown hues in calcalkaline rocks to shades of yellow or green in peralkaline rocks. These rocks are easily broken by a hammer and can be deeply scratched by a knife under pressure. Zeolite crystals are microcrystalline except for sparse occurrences in openings along faults and fractures and occasionally in pumice.

On Rainier Mesa, complete alteration of volcanic rocks to zeolites or clay minerals rouyhly parallels the bedding, but the alteration may cross stratigraphic boundaries (Hoover, 1968). A transition zone between completely altered rocks and vitric rocks ranyes from less than $3 \mathrm{ft}$ to more than $b 0 \mathrm{ft}$ thick. Both calc-alkaline and peralkaline nonwelded ash-flow tuffs, ash-fall tuffs, reworked ash-fall tuffs, and tuffaceous sandstones may be zeolitized.

\section{Argillized rocks}

Volcanic rocks that contain visibly recognizable clay minerals are termed argillized rocks. Nearly all zeolitized rocks and some vitric rocks contain small amounts clay, but some beds contain enough clay to produce slaking. The clay content ranges from enough to cause slaking after a core is dried in air to complete disintegration when a core is immersed in water. Argillized rocks are easily carved with a knife. Argillized beds are less common in peralkaline than calc-alkaline rocks. Dark-hued rocks are often argillized, but the more abundant light-colored rocks may contain equal or greater amounts of aryillization. In some ash-fall tuffs, pumice is argillized in a zeolitized matrix. 


\section{Silicified rocks}

Silicified beds, usually less than 15 in thick, are scattered throughout zeolitized and argillized volcanic rocks and are more common in calc-alkaline than in peralkaline rocks. Silicified beds are usually light-colored tuffaceous sandstones and very fine grained ash-fall tuffs, but thin ash-fall tuffs and reworked ash-fall tutfs are occasionally silicified. The silicification of individual beds, particularly throughout a tunnel complex or larger area, indicates that most of the silicification is probably part of the yround-water alteration of the volcanic rocks. At a few locations, darkerhued ash-fall tuffs are silicified at the top. The silicification has caused lightening of the color or a change from red or brown to light gray that has an irregular lower boundary. This alteration of ash-fall tuffs is not continuous and may be the result of weathering while the ash-fall tuffs were exposed at the surface. Silicified beds are difficult to break with a hammer. A knife produces only faint marks in silicified rocks.

\section{Paleocol luvium}

Quartzite, schist, and quartz monzonite clasts occur at the base of the volcanic rocks in a matrix that contains variable amounts of clay minerals and tuff. Volcanic clasts are sparse in the paleocolluvium. The clasts range in size from pebbles to large boulders, but most of the clasts are less than 8 inches in diameter. The matrix consists of clay minerals that were probably produced by weathered pre-volcanic rocks and disinteyrated tuff. In the UE12n\#10 arill hole, the matrix is almost entirely reworked ash-fall tuff and tuftaceous sandstone. Typically, the paleocolluvium is moderate reddish brown to reddish brown. Where tuff comprises most of the matrix, the color may be moderate reddish oranye to pale reddish brown. Bedding in the paleocolluvium in the U12n area is sparse to absent. Thickness of the paleocolluvium in the U12n area ranges from $2 \mathrm{ft}$ in the UE12n\#3 arill hole to more than $180 \mathrm{ft}$ in the UE12n\#11 drill hole where the base of the paleocolluvium was not reached. The top of the paleocolluvium is defined by the upward disappearance of clasts of pre-Tertiary rocks laryer than 2 inches in diameter.

Paleocolluvium may also be indicated by smaller clasts combined with a lack of bedding and volcaniclastic textures and an abundance of clay for more than 10 ft.

Paleocolluvium is not present in the U12b.07-2 drill hole, but is present in other drill holes in the U12n area. On the north side of the Rainier Mesa syncline, paleocolluvium is thicker to the east in the UEl2n\#2, n\#10, and n\#11 drill holes ( 8 to more than $180 \mathrm{ft}$ ) than to the west in the UE12n\#3, $n \# 8$, and n\#y drill holes $(2-21 \mathrm{ft})$. West of the U12n area, the paleocolluvium is $66 \mathrm{ft}$ thick in the RME-1 arill hole and so ft thick in the U12r drill hole. Differences may be caused by local paleotopography or by post-colluvium erosion.

\section{Older Tuffs}

Litholoyic logs (D.R. Miller, U.S. Geological Survey, written commun., 1970; Maldonado and others, 197y) have included part or all of the volcanic rocks below tunnel bed 2 in older tutfs. Older tuffs in some drill holes have included, in ascending order, bedded tuff, the Fraction Tuff, bedded tuff, the Redrock Valley Tuff, tunnel bed 1, and the tuff of Yucca Flat. The ash-flow tuffs (Fraction and Redrock Valley Tuffs and the tuff of Yucca Flat) vary greatly in thickness and are not present in some arill holes. 
Ulder bedded tuffs contain more clay and red colors than tunnel bed 2, but the older bedded tuffs cannot be differentiated in the absence of the ashflow tuffs that separate them. In contrast to the older tuffs, tunnel bed 2 and younyer stratigraphic units have a relatively uniform variation in thickness and are present throughout the U12n area. In the UEI2n\#3 drill hole, older tuffs are not present and tunnel bed 2 rests on paleocolluvium. Erosion over a paleotopographic hiyh of pre-Tertiary rocks nay be the cause of thin or absent older tuffs in the area of UE12n\#2, $n \# 3, n \# 8$, and $n \# 9$ drill holes.

\section{Fraction Tuff}

The Fraction Tuff, as originally described (Ekren and others, 1971) contains 2U-54 percent phenocrysts. In contrast, the Redrock Valley Tuff and the tuff of Yucca Flat contain less than 20 percent phenocrysts. The Fraction Tuff also contains more quartz, 18-4U percent (table 3 ) of the phenocrysts, in contrast to 0-6 percent in the Redrock Valley Tuff (Byers and others, 1976) and $y-24$ percent in the tuff of Yucca Flat (Carr and others, 1984). Although biotite as a percentage of phenocrysts is similar in the three ash-flow tuffs, the biotite content of the Fraction Tuff is much greater because of the higher content of phenocrysts. Biotite and hornblende in the Fraction Tuff range from 0 to 9 percent of the phenocrysts (Ekren and others, 1971).

North of Rainier Mesa in the Nellis Bombiny and Gunnery Range, the Fraction Tuff is pinkish gray, pale brown, and light red, and contains several cooling units and intercalated ash-fall tuffs. The maximum thickness is about $7,200 \mathrm{ft}$. In Test Well 8 (TWy), southwest of Rainier Mesa, the Fraction Tuff is $1,150 \mathrm{ft}$ thick. The tuff is present just west of the Ui2n area in the RME-1 drill hole $(3,391-3,528 \mathrm{ft})$. Ash-flow tuffs of the Fraction Tuff have not been identified in the U12n area, but may be present in the UE12n\#8 drill hole. In UE12n\#8, the ash-flow tuff between 1,563 and $1,583 \mathrm{ft}$ that may be the Fraction Tuff is grayish orange to yrayish orange pink, contains abundant biotite and other phenocrysts and some ash-fall tuffs, and overlies pal eocolluvium.

The age of the Fraction Tuff is between 16 and $18 \mathrm{m.y}$. In the Nellis Bombing and Gunnery Ranye, ayes of $15.7 \pm U .5$ and $16.4+U .5$ m.y. were determined

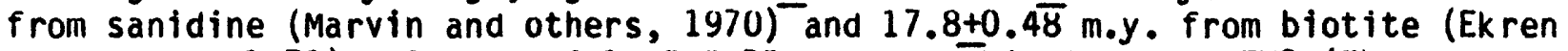
and others, 1971). An age of $15.0 \pm 0.55 \mathrm{m.y}$. for biotite from TW8 (Ekren and others, 1971) is probably too young because of alteration or heating at the edge of the Timber Mountain and Silent Canyon calderas.

\section{0lder bedded tuffs}

Bedded tuffs that underlie tunnel bed 2 have been identified as older bedded tutfs and the overlying tunnel bed 1 or as older bedded tuffs only (Maldonado and others, 1979). Older bedded tuffs can only be distinguished from tunnel bed 1 if the Redrock Valley Tuff is present beneath tunnel bed 1. Ulder bedded tuffs can be identified in the U12n area only in the UE12n\#8 drill hole where these tuffs are intercalated with ash-flow tuffs that may be the Fraction Tuff. 
The older bedded tuffs in other parts of Rainier and Aqueduct Mesas resemble tunnel bed 1 and the lower part of tunnel bed 2 in color and lithology. Colors range from shades of gray, orange, and pink, to reds and reddish browns. Shades of green are not present in the older bedded tuffs in contrast to their presence in tunnel bed 2. Moderate to dark hues of reddish brown and red may be more abundant in the older bedded tuffs than in tunnel beds 1 and 2, but the amount of older bedded tuffs penetrated in drill holes is too small to be certain of this. The older bedded tuffs do not contain peralkaline tufts, but this lack is also characteristic of tunnel bed 1 and the lower part of tunnel bed 2. Zeolitized, silicified, or argillized beds in the older bedded tuffs of other areas appear to resemble tunnel beds 1 and 2 .

Where the Redrock Valley Tuff is absent, older bedded tuffs and tunnel bed 1 should be combined. Where the tuff of Yucca flat is also absent, then older bedded tuffs, tunnel bed 1, and the lower part of tunnel bed 2 that lacks peralkaline tuffs should be combined because lithologic differences cannot be distinguished where these ash-flow tuffs are not present.

\section{Kedrock Valley Tuff}

The Redrock Valley Tuff is a single ash-flow cooling unit named for Redrock Valley just south of Rainier Mesa (Byers and others, 1976). In the $U 12 n$ area, this tuft was penetrated in the UE12n\#2, $n \# 8$, and U12b.U7-2 drill holes (D.R. Miller, U.S. Geological Survey, written commun., 1970; Maldonado and others, 1979). Thicknesses in these drill holes are 26, 19, and $113 \mathrm{ft}$, respectively. The Redrock Valley Tuff is apparently not present in the UE12n\#3, n\#9, n\#1U, and $n \# 11$ drill holes. In the RME-1 drill hole, the thickness is $592 \mathrm{ft}$. Southwest of Rainier Mesa, the Redrock Valley Tuff has a maximum thickness of $1,370 \mathrm{ft}$ in TW8. In the Ui2n area and elsewhere beneath Rainier Mesa, the thickness of the Redrock Valley Tuff is apparently affected by paleotopography and post-depositional erosion.

In the U12n area, the Redrock Valley Tuff is yrayish orange pink, very pale oranye, and moderate reddish orange, devitrified, and nonwelded to partly welded. In the RME-1 drill hole, just west of the U12n area, the tuff contains intervals that are brown to moderate-reddish-brown color, densely welded, and mostly devitritied to zeolitized. Quartz phenocrysts are absent to very sparse and rarely can be seen with a hand lens. The tuff contains pumice lenticles 0.4-0.8 in long. The pumice contains abundant biotite and hornblende phenocrysts that are $U .04$ in or less in length. Sparse quartz phenocrysts, presence of biotite and hornblende in the pumice, and less than 20 percent phenocrysts are the major characteristics that distinyuish the Redrock Valley Tuff from the Fraction Tuff and the tuff of Yucca Flat (table 3).

The age of the Kedrock Valley Tuff, determined on sanidine from the type locality, is 15.7+0.6 m.y. (Marvin and others, 1970). 


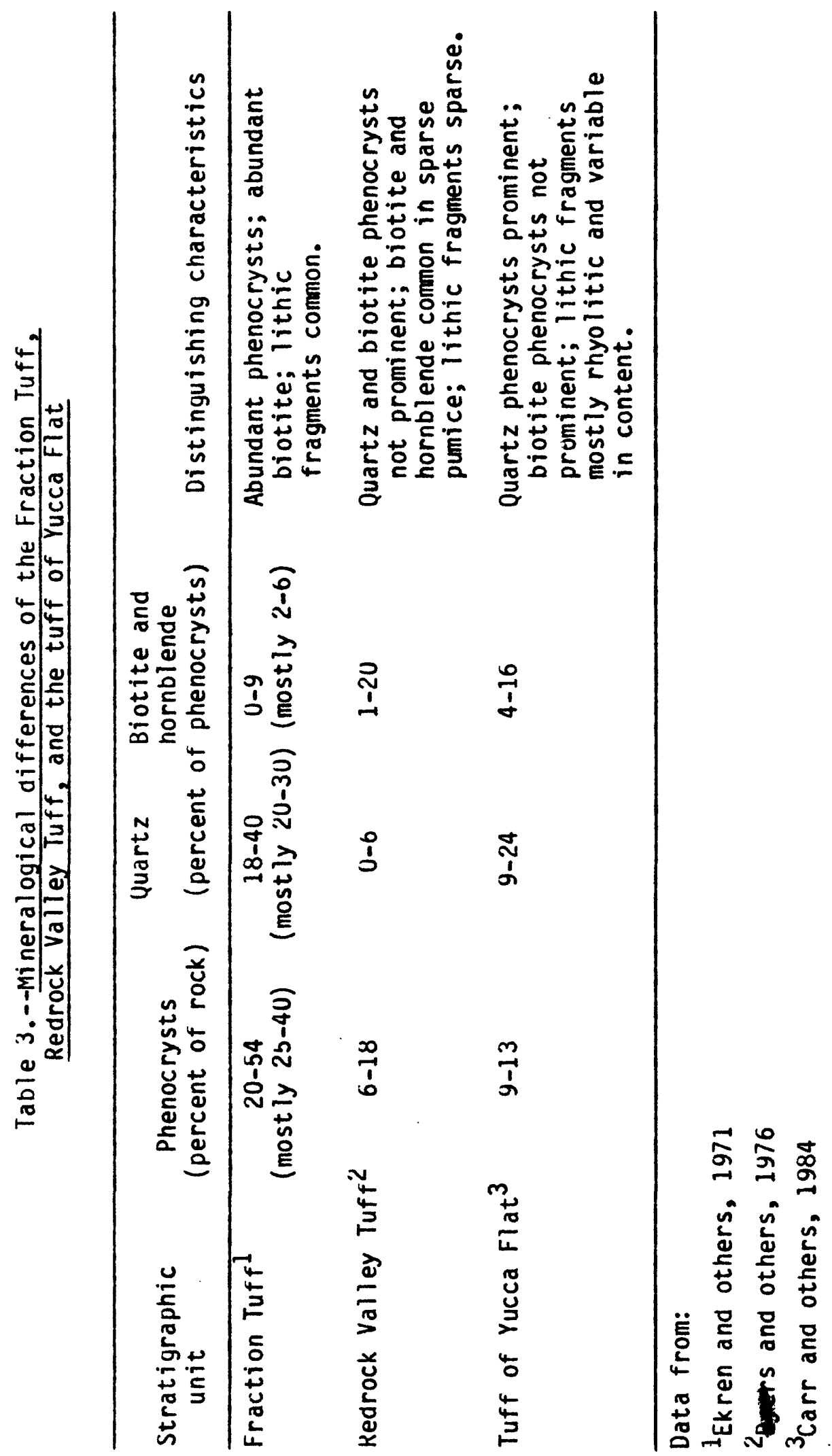




\section{Tunnel Beds}

Bedded tuffs were initially mapped as four informal stratigraphic units on the east side of Rainier Mesa (Gibbons and others, 1963): tunnel beds 1-4. In the underyround mapping of the tunnels and in vertical drill holes on Rainier Mesa, this nomenclature has been continued. The definition of the Belted Ranye Tuff and its two members, the Tub Spring and Grouse Canyon, deleted the peralkaline ash-fall tuffs beneath the Grouse Canyon Member as the lower part of that member (Saryent and others, 1965). These ash-fall tuffs have since been informally called tunnel bed $b$.

Ash-flow tuffs of the tutf of Yucca Flat and the Tub Spring Member of the belted Ranye Tuff are intercalated between tunnel beds 1 and 2 and between tunnel beds 2 and 3 , respectively. Although these ash-flow tuffs are not part of the tunnel beds as originally defined, they are included in this report under tunnel beds so that they may be described in stratigraphic sequence.

When underground mapping of the tunnel beds beyan, each tunnel bed was informally subdivided into mapping subunits designated by letters. Lack of exposure underyround, sparse data in drill holes, variable thickness, and the lack of distinctive beds have led to the discarding of letter subunits in tunnel beds 1 and 2. In tunnel beds 3 and 4, some letter subunits have been combined because distinctive beds or contacts are not everywhere present.

\section{Tunnel bed 1}

Tunnel bed 1 is defined as the bedded tuffs that occur between the Redrock Valley Tuff and the tuff of Yucca Flat. The only location in the U12n area where bedded tuffs occur between these two ash-flow tuffs is in the UE12n\#2 drill hole. Bedded tuffs identified as tunnel bed 1 in the UE12n\#10 drill hole (Maldonado and others, 1979) are probably the lower part of tunnel bed 2. The addition of these beds to those identified as tunnel bed 2 would make the total thickness $146 \mathrm{ft}$, similar to thicknesses of 1b3.5-187 ft of tunnel bed 2 in six holes in the U12n area (U.R. Miller, U.S. Geological Survey, written commun., 1970; Maldonado and others, 1979). In the UEl2n\#11 arill hole, bedded tuffs identified as tunnel bed 1(?) are mostly shades of reddish brown and may be older tuffs. Near the working point (WP) of the U12n.10 tunnel, tunnel bed $l$ is absent or cannot be distinguished from tunnel bed 2 because the tuff of Yucca $F 1$ at is not present.

Tunnel bed 1 consists of yellowish-yray, yrayish-oranye-pink, moderatereddish-brown, and small amounts of pale-red and dark-reddish-brown, reworked ash-fall tuff, ash-tall tuff, and tuffaceous sandstone. Peralkaline tuffs are not present. Most of tunnel bed 1 is zeolitized, but thin silicified beds are present throuyhout the unit. Tunnel bed 1 resembles the lower part of tunnel bed 2 in lithology and color and may not be distinguishable from tunnel bed 2 in the absence of the tuff of Yucca Flat. Tunnel bed 1 is $27 \mathrm{ft}$ thick in the UEl 2n\#2 arill hole, but it is as much as $147 \mathrm{ft}$ thick elsewhere beneath Rainier Mesa. 
The tuff of Yucca Flat, formerly called the tuff of Crater Flat in the Rainier Mesa area (Carr and others, 1984), is present in the UE12n\#2, $n \# 6$, n\#8, and U12b.07-2 drill holes (D.R. Miller, U.S. Geological Survey, written commun., 1970; Maldonado and others, 1979). The ash-flow tuff in UE12n\#11 between 1,611 - and 1,661-ft depth, identified as an older Tertiary tuff (Maldonado and others, 1979), is probably the tuff of Yucca Flat. The tuff of Yucca Flat is not present in the UE12n\#3, $n \# 9$, and $n \# 10$ drill holes.

The tuff of Yucca Flat is a simple cooling unit of nonwelded to partially welded ash-flow tuff. Colors range from yellowish gray, grayish pink, and moderate orange pink to pale red and pale to moderate reddish brown. Quartz phenocrysts are relatively abundant and comprise 9 to 24 percent of the phenocrysts (table 3 ). Thickness varies from $16 \mathrm{ft}$ in UE12n\#2 to greater than $195 \mathrm{ft}$ in UE1 $2 n \# 6$. In the RME-1 and U12b.07-2 drill holes, the thicknesses are 164 and $24 \mathrm{~b} \mathrm{ft}$ respectively. The tuff of Yucca Flat is younger than the Redrock Valley Tuff and older than the rhyolite lava of Kawich Valley. These units limit the aye of the tuff of Yucca Flat to between 13.7 and $14.8 \mathrm{~m} . \mathrm{y}$. (Carr and others, 1984).

\section{Tunnel bed 2}

Tunnel bed 2 is the oldest stratigraphic unit that is continuous throughout the Rainier Mesa area. Tunnel bed 2 is defined as the bedded tuffs that lie between the tuff of Yucca Flat below and the Tub Spring Member of the Belted Range Tuff above. Peralkaline bedded tuffs that have been included with the Tub Spring Member in some drill-hole logs (Maldonado and others, 1979) are included in tunnel bed 2 in this report because the Tub Spring Member is defined as an ash-flow tuff (Sargent and others, 1966).

The colors of tunnel bed 2 are predominantly light shades of gray, pale orange, orange pink, and yellow orange. Peralkaline rocks, present only in the upper part, range in color from greenish yellow to pale olive. Light to moderate shades of red, reddish brown, and brown are present throughout tunnel bed 2. The litholoyy is predominantly calc-alkaline rocks and a majority of the rocks are reworked ash-fall tuff and tuffaceous sandstones. Most of tunnel bed 2 is zeolitized. Silicified beds are mostly calc-alkaline.

Tunnel bed 2 contains the oldest peralkaline bedded tuffs in the U12n area. These peralkaline tuffs are thought to be correlative to the rhyolite lava of Kawich Valley (Carr and others, 1984), the oldest known stratigraphic unit of the Silent Canyon caldera that is dated at $14.8+0.6$ m.y. (Marvin and others, 1970).

The base of tunnel bed 2 is located at the top of the tuff of Yucca Flat. Because the top of the tuff of Yucca Flat lies below the rhyolite lava of Kawich Valley, the oldest known peralkaline unit of the Silent Canyon caldera, the base of tunnel bed 2 lies below the lowest peralkaline bedded tuffs in the tunnel beds. The upper contact of tunnel bed 2 is at the base of the Tub Spring Member or, where this ash-flow tuff is not present, at the base of the massive calc-alkaline ash-fall tutts of tunnel bed $3 A$. A pisolitic bed, present in the upper $100 \mathrm{ft}$ of tunnel bed 2, varies from pale red to moderate orange pink in color. Liyhter and darker shades are present in gradational bands and within individual pisolites. The pisolites range from 2-4 inches in diameter and commonly are broken. The pisolite bed varies from 4-12 inches in thickness. 
The thickness of tunnel bed 2 ranges from $153.5-187 \mathrm{ft}$ in six vertical arill holes (D.R. Miller, written commun., 1970; Maldonado and others, 1979). In the UEl 2n\#10 drill hole, the thickness was logyed as $33 \mathrm{ft}$, but the tuff of Yucca Flat is not present. If bedded tuffs identitied as tunnel bed 1 and ash-fall tuffs included in the Tub Spring Member are added to tunnel bed 2 , then the actual thickness of tunnel bed 2 in UE12n\#10 is $146 \mathrm{ft}$.

\section{Tub Spring Member of the Belted Range Tuff}

The Tub Suring Member is a peralkaline, ash-flow tuff (Sargent and others, 1964). In the UE12n\#1 drill hole, this tuff is pale reddish brown to light brown, partially to densely welded, and devitrified. In the U12n.10 drifts, the tuff is thin, pale to moderate yreenish yellow to grayish yellow and reddish oranye, nonwelded, and zeolitized. Phenocrysts, that include abundant quartz, may comprise $20-25$ percent of the tuff. Thickness of the Tub Spring Member ranyes from 2-65 ft in nine vertical drill holes. The maximum thickness, northeast of Rainier Mesa, is about $300 \mathrm{ft}$ (Sargent and others, 1965). The age of the Tub Spring Member has not been determined, but the tuff overlies the rhyolite of Kawich Valley about 5 miles northwest of Rainier Mesa and is therefore less than $14.8 \mathrm{m.y}$. old.

The Tub Spring Member was deposited over most or all of the U12n area, but thins toward structural highs and may be absent in other parts of Rainier Mesa. Erosion is not evident at the top of the Tub Spring Member and the thinning or absence of this tuff is probably depositional.

Tunnel bed 3

Tunnel bed 3 contains three subunits, $3 \mathrm{~A}, 3 \mathrm{BC}$, and $3 \mathrm{D}$, that are continuous in the U12n area. The lower and upper subunits are almost entirely massive ash-fall tuffs. The midale subunit is a sequence of thin-bedded ashfall tuft, reworked ash-fall tuffs, and tuffaceous sandstones. Total thickness of tunnel bed 3 in the U12n area ranges from 89-2bl $\mathrm{ft}$ (D.R. Miller, U.S. Geoloyical Survey, written commun., 19\%; Maldonado and others, 1979); data from vertical drill holes indicate that thicknesses less than $150 \mathrm{ft}$ are probably the result of section omitted by faults.

Subunit $3 A$.- -The subunit is almost entirely moderate-reddish-brown to moderate-reddish-orange, massive ash-fall tuff. Less than 1 percent consists of pale-reddish-brown, grayish-orange-pink, and moderate-orange-pink, thin bedded, calc-alkaline reworked ash-fall tuffs and tuffaceous sandstone and thin beds of pale-yellowish-brown peralkaline ash-fall tuff. Lithic fragments and pumice are not prominent in subunit $3 A$. Most of the subunit is zeolitized. Most of the argillized and silicifled beds are calc-alkaline ashfall tuff. Thickness of subunit $3 A$ varies from $15-46 \mathrm{ft}$ in eight vertical drill holes (D.R. Miller, U.S. Geological Survey, written commun., 1970; Maldonado and others, 1979). The massive, red to brown ash-fall tuff of subunit $3 A$ and its location overlying the Tub Spring Member make this subunit a ,prominent marker bed throughout the Rainier Mesa area. 
Subunit 3BC.--Originally mapped as two separate subunits, subunits $3 B$ and $3 C$ have been combined because their contact could not be identified everywhere with certainty in the Rainier Mesa area. Subunit 3BC contains mostly calcalkaline rocks that are about half ash-fall tuff and half reworked ash-fall tuff and tuffaceous sandstone. The calc-alkaline rocks are grayish orange pink, moderate reddish brown to orange, moderate to light red, and moderate oranye pink and are thin to thick bedded. Peralkaline rocks occur as thin to thick beds throughout the subunit. Peralkaline rocks are grayish yellow, pale yellow brown, and very pale orange, and consist of almost equal amounts of ash-fall tuff and reworked ash-fall tuff. Lithic fragments comprise b-15 percent of some peralkaline ash-fall tuffs. Individual beds may be argillized or silicified, but most of subunit $3 \mathrm{BC}$ is zeolitized. Argillized and silicitied beds are mostly calc-alkaline rocks. The thickness of subunit 3BC in seven vertical arill holes ranges from bl-lub $f t$.

The base of subunit $3 \mathrm{BC}$ is defined by the massive character and reddishbrown color of subunit $3 A$; the top of $3 B C$ by the similar appearance of subunit 30.

Subunit 30.--The subunit is almost entirely calc-alkaline, massive ashfall tuff. Cotors are mostly moderate to dark reddish brown, moderate reddish orange, and yrayish orange pink. At some locations, the uppermost 3-10 ft appear to be bleached to yrayish orange to pale reddish brown in color. The contact of the bleached colors with the darker colors below is irregular. The bleached rocks are silicified at some locations. The calc-alkaline rocks contain small amounts of reworked ash-fall tuff and tuffaceous sandstone that are usually liyhter shades of the adjacent ash-fall tuffs. In the lower onethird of subunit 30, a single bed of peralkaline ash-fall tuff occurs at some locations. The bed is less than $3 \mathrm{ft}$ thick and may grade into calc-alkaline ash-fall tuff above. The color of the peralkaline bed is pale yellowish brown to grayish orange. Pumice ranyes from $1-1 / 2$ in long. Pumice colors are lighter than the matrix, and range from almost white to pale orange pink to pale yellowish yray. Lithic fragments are not prominent in subunit 30. Thickness of subunit 30 ranges from $29-57 \mathrm{ft}$ in seven vertical drill holes. Subunit 3D closely resembles subunit $3 A$, but 30 has laryer and more abundant pumice. The massive ash-tall tuff and its position between thin-bedded subunits make the subunit a marker horizon throughout Rainier Mesa.

Tunnel bed 4

Tunnel bed 4 contains seven stratigraphic subunits. Subunits $4 A-D$ and $4 F$ contain less ash-fall tuff than the other subunits. Subunit $4 \mathrm{G}$ is predominantly peralkaline tuff; other subunits are mostly calc-alkaline tuff. Total thickness of tunnel bed 4 varies from 338-465 ft in eight vertical drill holes, but drill hole data indicate that thicknesses less than $375 \mathrm{tt}$ may be caused by beds omitted by faults.

Subunit 4A-1.--Subunit 4A-D combines four subunits that cannot be recoynized throughout the Rainier Mesa area. The subunit is mostly grayish yellow to yellowish yray and grayish orange pink with sparse, thin beds of pale to moderate reddish brown, moderate reddish orange, dusky yellow, and pale yellowish brown. The base of the subunit is commonly a peralkaline ashfall tuff less than $3 \mathrm{ft}$ thick that contains 5-10 percent lithic fragments as larye as 4 inches in diameter. The color of this basal bed is grayish yellow 
to dusky yellow. Where this bed is not present, the base is recognized by the underlying massive calc-alkaline ash-fall tuffs of subunit 3D. Beds in subunit $4 A-U$ range trom $1 \frac{1}{2}$ in to $3 \mathrm{ft}$ in thickness. Most beds are less than 1-ft thick. The subunit is mostly calc-alkaline tuff. More than half of the subunit is ash-fall tuff. Argillized and silicified beds are mostly calcalkaline rocks. The top of subunit $4 A-D$ is commonly a peralkaline ash-fall tuff similar to the basal bed. In the absence of subunit $4 E$, the top of subunit $4 A-D$ may not be distinguishable from subunit $4 F$. Thickness of subunit $4 A-U$ ranges from 41-y6 ft in six vertical drill holes.

Subunit 4E.--The subunit is mostly massive, calc-alkaline, ash-fall tuffs that commonly contain large lithic fragments. Subunit $4 E$ is moderate-reddishbrown to reddish-orange ash-fall tuffs with lesser amounts of reworked ashfall tuffs, tuffaceous sediments, and peralkaline ash-fall tuffs that are grayish orange pink, grayish yellow, moderate orange pink and pale yellowish brown. Subunit $4 E$ contains $5-15$ percent volcanic lithic fragments that are commonly larger than 2 in and may be as large as 10 inches in diameter. The largest lithic fragments are in the basal 3-6 ft. The lithic fragments are black to very dark reddish brown and commonly have a rind that is moderate to dark reddish brown and $0.2-1$ in thick. Most of the subunit is zeolitized. Thickness of subunit $4 \mathrm{E}$ ranges from $19-42 \mathrm{ft}$ in five vertical drill holes.

Subunit 4E is recognized by the presence of massive ash-fall tuff, larye lithic trayments, more shades of red than other subunits in tunnel bed 4 , and the general lack of peralkaline ash-fall tuff. Where these characteristics are not well developed or not present, the lack of distinctive beds in the top of subunit $4 A-D$ and the base of subunit $4 F$ make the recognition of subunit $4 E$ difficult. In the UEl2n\#1 drill hole, subunit 4E lacks some of these characteristics and the contact with subunit $4 \mathrm{~F}$ is uncertain. In the UE12n\#3 drill hole, subunit $4 E$ was not recoynized and may not be present or may be included in subunit $4 \mathrm{~F}$.

Subunit 4F.--The unit is a heterogeneous mixture of mostly calcalkaline ash-fail tuff, reworked ash-fall tuff, and tuffaceous sandstone and small amounts of peralkaline bedded tuffs. The tuffs are mostly yellowish yray to yrayish yellow and yrayish orange pink to moderate orange pink with sparse beds that are reddish to moderate reddish brown. Beds are mostly less than $1 \mathrm{ft}$ thick and none is more than $3 \mathrm{ft}$ thick. Most of the subunit is zeolitized. Thickness of subunit $4 \mathrm{~F}$ ranges from $39-103 \mathrm{ft}$ in six vertical drill holes.

The predominant characteristics of subunit $4 \mathrm{~F}$ are the lithologic heterogeneity and thin beds. Absence of subunit $4 \mathrm{E}$ makes location of the lower contact of $4 \mathrm{~F}$ difficult to identify. Peralkaline ash-fall tuffs that are commonly present at the top of subunit $4 A-D$ have an aggregate thickness much yreater than $3 \mathrm{ft}$. In subunit $4 \mathrm{~F}$, peralkaline ash-fall tuffs are present only as individual beds less than $3 \mathrm{ft}$ thick that are present throughout the subunit. The top of subunit $4 \mathrm{~F}$ is at the top of a silicified tuffaceous sandstone. The sandstone varies from pale pink to grayish orange pink to moderate pink or orange pink. Thickness of the sandstone ranges from 2-12 inches. The sandstone is always present except in sparse, shallow channels that are $b-2 b \mathrm{ft}$ wide that were eroded in the top of subunit $4 \mathrm{~F}$ prior to deposition of subunit $4 \mathrm{G}$. The sandstone is underlain by a calc-alkaline ashfall tuft that is pale yellowish brown to pale red to light brownish yray, and 
contains abundant grayish yellow to pale yellowish orange pumice that is 1-2 inches in diameter.

Subunit 4G. --The subunit is a sequence of predominantly peralkaline ashfall tuffs. The tuffs are mostly very pale orange, grayish yellow, and grayish oranye pink. Calc-alkaline reworked ash-fall tuff and tuffaceous sandstone are interbedded with peralkaline ash-fall tuff in the basal 3-6 ft of the subunit, and grade upward into peralkaline ash-fall tuff that contains few, if any, thin beds of calc-alkaline bedded tuffs. Lithic fragments are present throughout the subunit and are rarely more than 2 inches in diameter. Most of the subunit is zeolitized. Thickness of the subunit ranges from 14-28 ft in nine vertical drill holes.

Subunit $4 G$ is characterized by the predominance of peralkaline ash-fall tutf, a lack of shades of red, and small lithic frayments throughout the subunit. The top of subunit $4 \mathrm{G}$ is at the base of the first bed with red colors. The red colors in subunit $4 H$ may be light-pink coloration of the matrix around very pale orange pumice, or pink to light-red color in a bed, or splotches of light to moderate red. The red colors are in a single bed. Ashfall tuffs in the base of subunit $4 \mathrm{H}$ may resemble beds in the upper part of subunit $4 \mathrm{G}$.

Subunit 4H.--The subunit is mostly calc-alkaline bedded tuffs. Color ranges from yellowish gray to grayish yellow and yellowish brown to brownish gray and moderate brown. A few thin red beds occur in the lower half of the subunit. Moderate-reddish-brown, very pale orange to grayish-orange-pink, and pale- to moderate-greenish-yellow beds are present throughout the subunit. Subunit $4 \mathrm{H}$ is mostiy calc-alkaline tuff. Thickness of subunit $4 \mathrm{H}$ ranges from $30-45 \mathrm{ft}$ in nine vertical drill holes.

Subunit $4 \mathrm{H}$ has no distinguishing characteristics by itself, but differs from both subunit $4 G$ and $4 \mathrm{~J}$. The presence of brown and moderate-red colors and sparse lithic fragments distinguish subunit $4 \mathrm{H}$ from subunit $4 \mathrm{G}$. Thin beds and lesser amounts of brown or red colors distinguish subunit $4 \mathrm{H}$ from the thick to massive beds and predominantly brown to red colors of subunit $4 \mathrm{~J}$.

Subunit 4J.--The subunit is predominantly calc-alkaline ash-fall tuffs. colors are mostly browns or reds that range from moderate red brown to pale yellow brown and yellow brown to pale brown and moderate brown. A few yrayish-yellow to yellowish-gray and moderate- to dusky-yellow beds are present in the lower and upper $1 \mathrm{U}-1 \mathrm{~b} \mathrm{ft}$ of subunit $4 \mathrm{~J}$. Argillization is more common in subunit $4 \mathrm{~J}$ than in older subunits, but argillization of $4 \mathrm{~J}$ in the UI2n area may be related to its position in the Rainier Mesa syncline and faultiny. Silicified rocks have not been found in subunit 4J. Thickness of subunit $4 \mathrm{~J}$ ranyes from $2 \mathrm{~b}-\mathrm{by} \mathrm{ft}$ in eight vertical drill holes.

The distinguishing characteristics of subunit $4 \mathrm{~J}$ are the thick to massive beds and the brown to red colors. Subunit 4K lacks the darker brown and red colors of subunit $4 \mathrm{~J}$ and contains thicker sequences of peralkaline ash-fall tutf. 
Subunit 4K.--The subunit is mostly calc-alkaline bedded tuffs, but grades from mostly calc-alkaline in the lower half to almost completely peralkaline in the upper 30-60 ft. Colors of zeolitized beds range from yellowish gray to grayish yellow and pale to moderate yellowish brown in the lower half to dusky yellow and olive yray to greenish yellow in the upper $60 \mathrm{ft}$. Vitric beds in subunit $4 \mathrm{~K}$ are light to moderate gray and greenish gray. Argillization in subunit $4 \mathrm{~K}$ is as common as in subunit $4 \mathrm{~J}$, probably for the same reasons. Thickness of subunit $4 \mathrm{~K}$ ranges from $82-185 \mathrm{ft}$ in five vertical drill holes, but thicknesses yreater than $110 \mathrm{ft}$ may include part of tunnel bed 5 .

The scarcity of brown and red colors except for scattered beds in the lower half and the presence of peralkaline tuffs more than $3 \mathrm{ft}$ thick distinguish subunit $4 \mathrm{~K}$ from subunit $4 \mathrm{~J}$. The upper part of subunit $4 \mathrm{~K}$ and all of tunnel bed 5 are entirely peralkaline tuffs. The top of subunit $4 \mathrm{~K}$ is at the top of the uppermost tuffaceous sandstone in these peralkaline tuffs. This sandstone ranges froil 2-12 inches in thickness.

\section{Tunnel bed 3}

Tunnel bed $b$, formerly the lower part of the Grouse Canyon Member, is comprised entirely of peralkaline ash-fall tuff. Calc-alkaline ash-fall tuff, peralkaline tuffaceous sandstone, and possibly peralkaline reworked ash-fall tuff, noted as tunnel bed $b$ in some drill holes, are probably part of subunit 4K. Where tunnel bed $b$ is zeolitized, the color ranges from pale to dark greenish yellow to dusky yellow. Where the stratigraphic unit is vitric, colors range from light to dark gray to yreenish gray. Argillized rocks have not been found in tunnel bed 5 . Thickness of tunnel bed $b$ ranges from 83-16b ft in eight vertical drill holes.

Tunnel bed $b$ closely resembles the upper part of subunit $4 K$, but the absence of calc-alkaline bedded tuffs, reworked ash-fall tuffs, and tuffaceous sandstones in tunnel bed $b$ distinguish it from subunit $4 k$. Where the Grouse Canyon Member is not present above tunnel bed $b$, a change to calc-alkaline bedded tuffs and the presence of reworked ash-fall tuffs and tuffaceous sandstones identify the tuffs of Area 20 and of Dead Horse Flat or the bedded tuffs of the Paintbrush Tuff.

\section{Grouse Canyon Member of the Belted Range Tuff}

The Grouse Canyon Member is a compound cooling unit of peralkaline ashflow tuff (Sargent and others, 196b). It is present in the U12n area only in the UE12n\#1, $n \# 5$, and $n \# 6$ drill holes. The tuff is light to moderate brown, moderate red brown, moderate to dusky red, and moderate yellowish brown, devitrified, and sliyhtly to mostly densely welded. Total phenocryst and lithic frayment content are less than $b$ percent in the U12n area. A tuffaceous conylomerate that underlies the Grouse Canyon Member in the UE12n\#1 drill hole is included in the member. The conglomerate contains abundant lithic frayment as large as 8 inches in diameter. The conglomerate may be a mud flow related to the Grouse Canyon Member, or it may be local ash-fall tuff of tunnel bed 5. It is included in the Grouse Canyon Member because the probable mud-flow origin is more likely to be related to the Grouse Canyon Member than to tunnel bed 5 . 
In the Rainier Mesa area, the Grouse Canyon Member was deposited only in topoyraphic lows (Gibbons and others, 1963). Near the axis of the Rainier Mesa syncline, tunnel bed $b$ is 91 and $82 \mathrm{ft}$ thick in the UEl2n\#l and n\#b drill holes, respectively. On the north flank of the syncline, tunnel bed 5 ranges from y3-148 ft thick in five drill holes. The thinning of tunnel bed $b$ at the base of the lirouse Canyon Member is the first evidence of major erosion above the base of tunnel bed 2. The limitation of the Grouse Canyon Member to topoyraphic lows indicates that deposition was probably 1 imited to these areas.

\section{Tuffs of Area 20 and of Dead Horse Flat}

The tuffs of Area 20 and of Dead Horse Flat are two informal units that were defined in drill holes on Pahute Mesa. These units are thickest within the Silent Canyon caldera west of Rainier Mesa (Orkild and others, 1969), but the maximum thickness outside the caldera is $300 \mathrm{ft}$ (Byers and others, 1976). In the U12n area, they have been identified only in the UE12n\#1 and $n \# 6$ arill holes (Maldonado and others, 1979). The tuff of Area 20 is calcalkaline and contains more lithic fragments than the Paintbrush Tuff. The tuff of Area 20 overlies the predominantly peralkaline tuff of Dead Horse Flat. The two tuffs have not been separated in the Rainier Mesa area, but both tuffs are probably present because both calc-alkaline, lithic-rich and peralkaline bedded tuffs have been logged in drill holes on Rainier Mesa.

The tuffs of Area $2 U$ and of Dead Horse Flat in the U12n area are pale to dark yellowish brown, very pale orange, dark yellow orange, and very light yray. These tuffs are mostly calc-alkaline ash-fall and reworked ash-fall tuffs. In the UE12n\#l drill hole, the tuffs are vitric and $202 \mathrm{ft}$ thick; in UEl $2 \mathrm{n} \# 6$, they are zeolitized and $269 \mathrm{ft}$ thick.

The presence of both calc-alkaline and peralkaline tuffs distinguishes the tuffs of Area 20 and of Dead Horse Flat from the peralkaline tuffs of tunnel bed $b$. Lithic fragments as large as 4 inches in diameter are common in the tuffs of Area $2 U$ and Dead Horse Flat, but 1 ithic fragments are small and sparse in the overlying bedded tuffs of the Paintbrush Tuff. Zeolitization may be more common in the tuffs of Area 20 and of Dead Horse Flat than in the Paintbrush, but the lower part of the bedded tuffs of the Paintbrush Tuff is zeolitized elsewhere on Rainier Mesa. Vitric tuffs of Area 20 and of Dead Horse Flat may be included as part of the Paintbrush Tuff in other drill holes of the U12n area, but identification only in the two drill holes nearest the synclinal axis suygests that the thickest section of the tuffs of Area 20 and of Dead Horse Flat may have. been deposited only in the bottom of the syncline or may have been removed by erosion on the flanks of the syncline.

\section{Stockade Wash Tuff}

The Stockade Wash Tuff (Byers and others, 1976) has been found only in the UEl $2 n \# 1, n \# 6$, and the RME-1 drill holes near the synclinal axis. The tuff is a white to light-yray and very light gray, nonwelded, vitric to zeolitized, calc-alkaline ash-flow tuff. In outcrop, the Stockade Wash Tuff is pale yellowish yray to light yellowish brown with orange pumice. In the subsurface, the pumice is somewhat darker than the color of the yroundmass. Biotite is present throughout the tuff. Lithic fragments are usually less than 2 inches in diameter and range from very sparse to less than $b$ percent. 
Thickness of the Stockade Wash Tuff is $10 \mathrm{ft}$ in UE12n\#1; $47 \mathrm{ft}$ in UE12n\#6; and more than $119 \mathrm{ft}$ in RME-1. The maximum thickness is about $375 \mathrm{ft}$ on the west and south sides of Rainier Mesa.

In Yucca Flat, the Stockade Wash Tuff intertongues with the tuffs of Area 20 and of Dead Horse Flat. These tuffs have not been recognized above the Stockade Wash Tuff on Rainier Mesa, but the lower part of the bedded tuffs of the Paintbrush may include these tutts in some drill holes.

\section{Bedded Tuffs of the Paintbrush Tuff}

The bedded tuffs of the Paintbrush Tuff (Byers and others, 19\%) are various shades of light to medium gray with a few beds that are pale yellowish brown, very pale oranye, and yrayish oranye pink. The tuffs are comprised of calc-alkaline ash-fall and reworked ash-fall tuffs and tuffaceous sandstone that are mostly vitric. A few beds may be slightly to mostly argillized or silicified. The lower one-quarter to one-third may contain zeolitized rocks. Pumice ranyes from sparse to very abundant. Lithic fragments are usually less than 2 inches in diameter and are usually sparse, but a few beds may contain b-1U percent. Thickness ranges from 442-652 ft in eight vertical drill holes.

The bedded tuffs of the Paintbrush Tuff can be differentiated from tunnel bed 5 by the lack of peralkaline beds and, in some beds, by sparse, small lithic fragments and sparse pumice. Peralkaline beds are not present in the bedded tuffs of the Paintbrush Tuff, in contrast to the tuffs of Area 20 and of Dead Horse Flat. Lithic fragments are less abundant and smaller in the Paintbrush Tuff than in the tuffs of Area 20 and of Dead Horse Flat. Massive bedding and pumice of contrasting color distinguish the Stockade Wash Tuff from the Paintbrush Tuff. Pale-pink or orange colors grading up to reddish colors and lack of beading distinguish the basal nonwelded part of the overlying Kainier Mesa Member of the Timber Mountain Tuff from the Paintbrush Tuff.

\section{Timber Mountain Tuff}

\section{Rainier Mesa Member}

The Kainier Mesa Member (Byers and others, 1976) is a compound cooling unit of calc-alkaline ash-flow tuff that caus Rainier Mesa. The basal 3U-7b ft ranyes from oranye pink to pale pink to pale red, and is nonwelded to partially welded. The upper part ranges from reddish gray to purplish gray, and is partially welded to mostly densely welded. The upper $60 \mathrm{ft}$ may contain a densely welded black vitrophyre at some locations on Rainier Mesa. Thickness of the Kainier Mesa Member ranges from 131-150 ft in six drill holes near the northern edge of Rainier Mesa. Near the synclinal axis, the tuff is $306 \mathrm{ft}$ thick in UEl $2 \mathrm{n \# l}$ and $412 \mathrm{ft}$ thick in UEl2n\#6. The age of the Rainier Mesa Member is $11.1 \mathrm{m.y}$. (Marvin and others, 1970).

\section{Bedded tuffs of the Amonia Tanks Member}

The bedded tuffs of the Ammonia Tanks Member crop out in an area $1,1 \mathrm{bU} \mathrm{ft}$ long and $350 \mathrm{ft}$ wide about $300 \mathrm{ft}$ east-northeast of the UE12n\#6 drill hole. The tuffs are light shades of gray and brownish gray, vitric, thin-bedded, and 
resemble the bedded tuffs of the Paintbrush Tuff. Maximum thickness is less than $15 \mathrm{ft}$. The welded tuff of the Ammonia Tanks Member is not present in the U12n area.

\section{Colluvium and Alluvium}

Colluvium is present on the steep sides of Rainier Mesa and as isolated patches on top of the mesa. The colluvium consists of mostly pebble- to boulder-sized fragments with space between the fragments partly to completely filled by sand-to clay-sized material. On the sides of Rainier Mesa, most of the colluvium is gravity controlled. On the top of the mesa, colluvium is mostly debris and wash controlled. Thickness of the colluvium ranges from $U$ to $30 \mathrm{ft}$, but most deposits are less than $1 \mathrm{~b} \mathrm{ft}$ thick.

Alluvium covers the bottom of the wash along the axes of the Rainier Mesa and Aqueduct synclines. The range in frayment sizes is similar to colluvium, but boulders are smaller and the alluvium contains more sand- and clay-sized material." Thickness ranyes from 0 to $15 \mathrm{ft}$. The aye of the colluvium and alluvium is not known, but it is probably Quaternary.

\section{DISTRIBUTION OF LITHULOGIES ANU ROCK ALTERATION}

Lithologic and alteration data recorded on colored strip loys from core in horizontal and vertical drill holes were compiled for each stratiyraphic unit (tables 4-6) ${ }^{2}$. Graphic data of these compilations show the relationships of litholoyies and rock alteration to stratiyraphic units (figs, $4, b$ ).

Except for subunit $4 G$ and tunnel bed $b$, bedded tuffs in all stratigraphic units contain at least 70 percent calc-alkaline rocks (table 4 , fig. $4 A$ ). Only a few feet of tunnel bed 1 have been cored, but this unit is apparently all calc-alkaline. The distribution of calc-alkaline ash-fall tuff roughly parallels the distribution of calc-alkaline rocks (table 4 , fig. 4A). Total ash-fall tuff decreases irregularly from about 97 percent in tunnel bed 5 to about 60 percent in subunit $4 A-D$, but has no systematic change, is irregularly distributed in tunnel beds 2 and 3 , and reaches a minimum of about 39 percent in tunnel bed 2 (table 4 , fig. 4A). The distribution of tuffaceous sandstone has a roughly inverse relationship to the distribution of ash-fall tuff (table 4, fig. 4B). This inverse relationship is an indication of reworking and erosion.

\footnotetext{
¿Lithologic and alteration data for horizontal and vertical drill holes were compiled separately and then combined. Percentages within a stratiyraphic unit should be the same reyardless of the orientation of drill holes, provided that the samples are from the same yeneral area and that samples are large enough. A few differences between horizontal and vertical holes were found to be related to location and are discussed in the text. Except for tunnel bed 2 , the total thickness corrected for dip of stratigraphic units penetrated in drill holes ranges from 4 to 10 times the true stratiyraphic thickness of each stratiyraphic unit.
} 


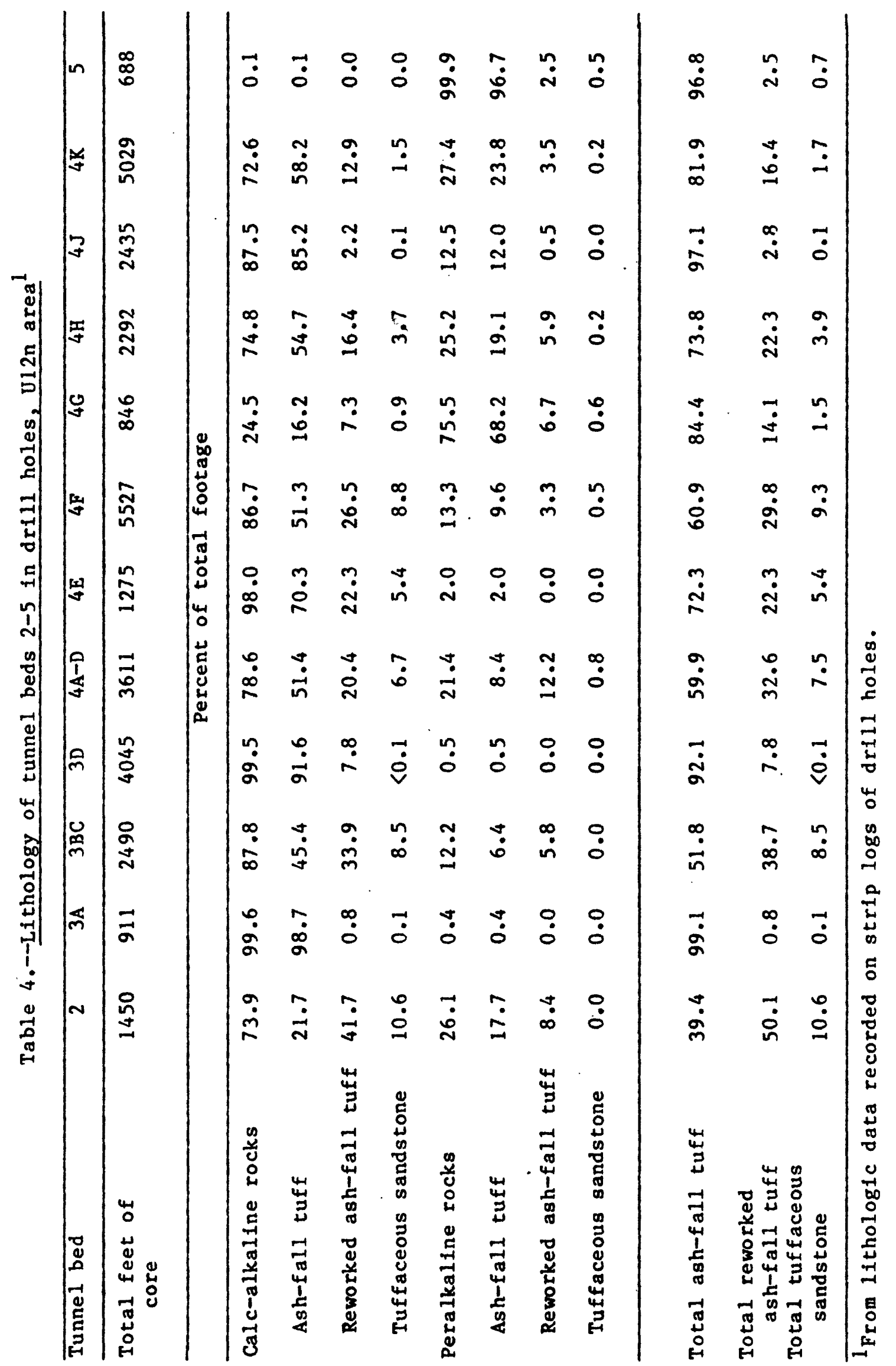




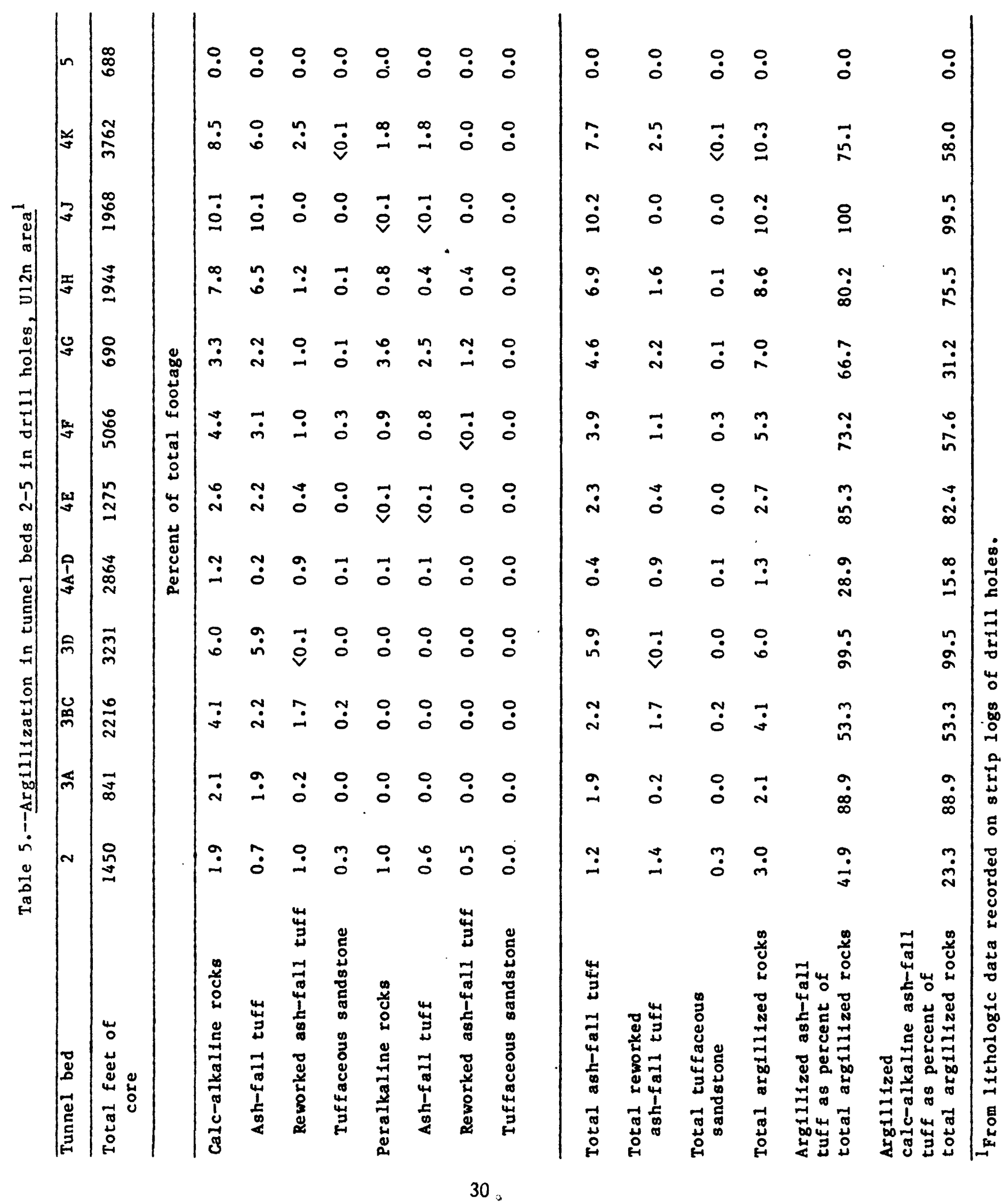




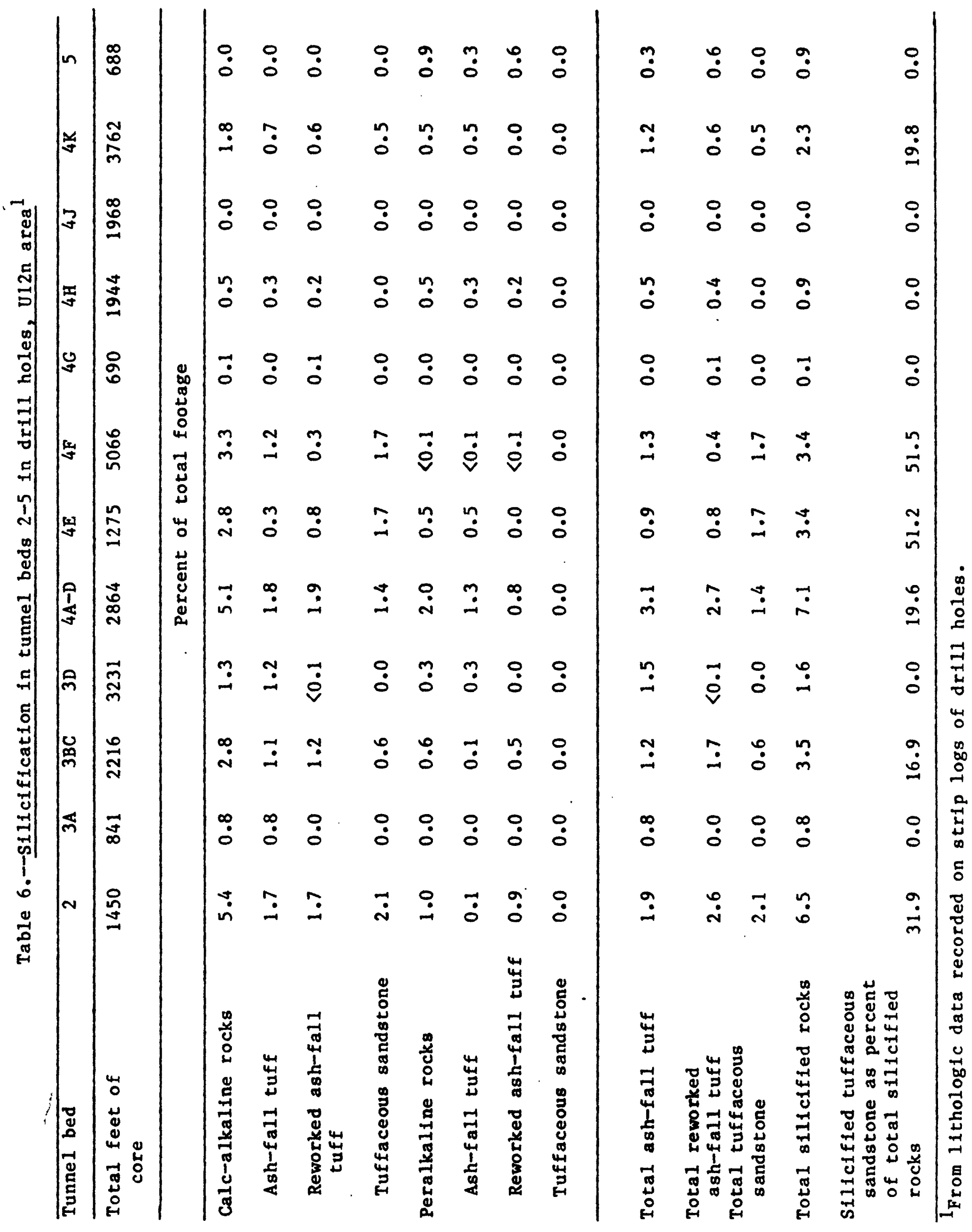



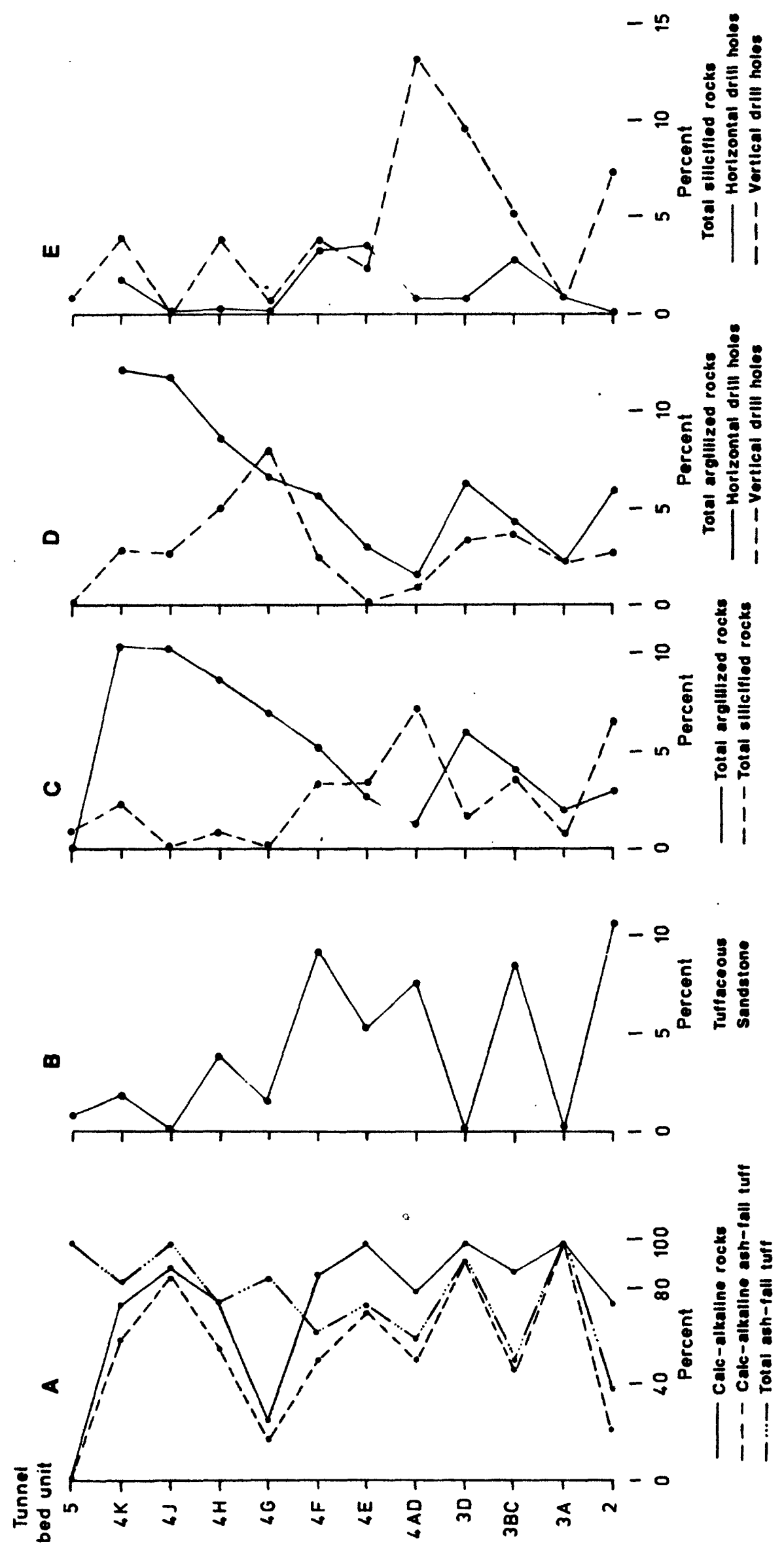

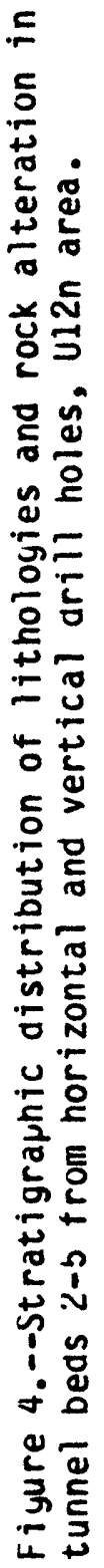



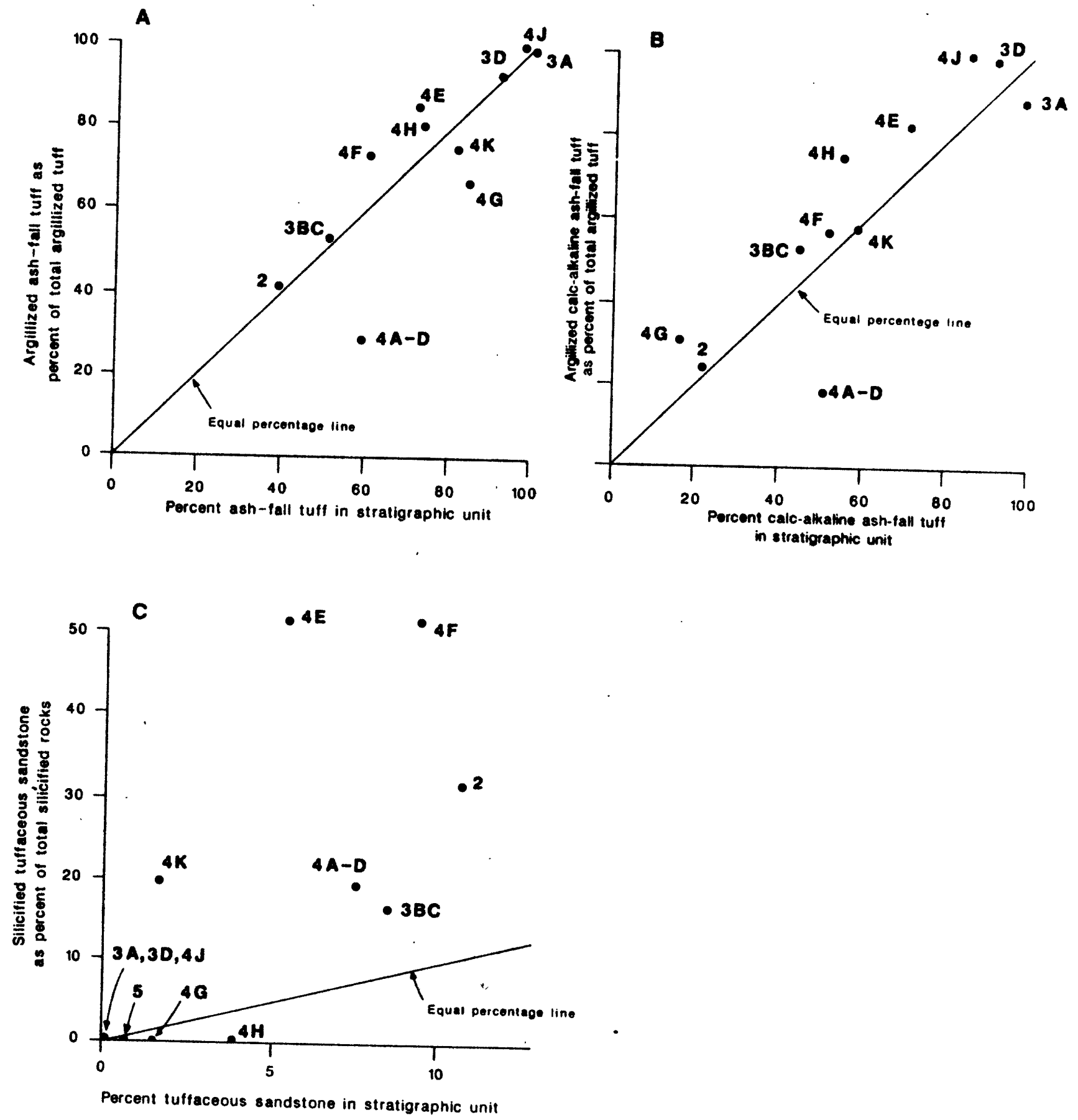

Figure 5.--Stratigraphic distribution of argillized ash-fall tuff, argillized calc-alkaline ash-fall tuff, and silicified tuffaceous sandstone compared to distribution of ash-fall tuff, calc-alkaline ash-fall tuff, and tuffaceous sandstone, respectively. 
Weatheriny and miyration of water have altered most of the formerly vitric bedded tuffs of tunnel beds $1-b$ and older volcanic rocks to zeolites, clay minerals, silica minerals, and probably feldspar (Hoover, 1968). An understanding of the distribution of the alteration products is needed for prediction of physical properties of volcanic rocks in unexplored areas.

\section{Zeolitization}

Zeolites are a significant alteration product in most subunits of tunnel bed 4 and all of the older rocks. The top of continuous zeolitization, below which vitric rocks are not present in bedded tuffs, varies in elevation in the U12n area, but the top is generally in subunit $4 \mathrm{~K}$ or tunnel bed 5 (table 7 ). In the UE12n\#6 and RME-1 drill holes, the top is in the Stockade Wash Tuff and the tuffs of Area 20 and Dead Horse Flat, respectively. Where the relationship between the top of zeolitization and faults can be observed or reliably inferred, faults displace the top of zeolitization and are, therefore, younger than the zeolitization.

The apparent top of zeolitization, where zeolites are first encountered, is $1 b-6 y b \mathrm{ft}$ above the top of continuous zeolitization in the U12n area. Variations in permeability may be the cause of irregular zeolitization above the top of continuous zeolitization (Hoover, 1968). Density log excursions apuear to be related to zeolitization in many holes (R.U. Carroll, U.S. Geological Survey, written commun., 198b), but are 19-20y $\mathrm{ft}$ below the top of continuous zeolitization (table 7 ). Although the density log excursions occur near the top of continuous zeolitization, the excursions are found over a larger stratigraphic ranye (table 7 ). 


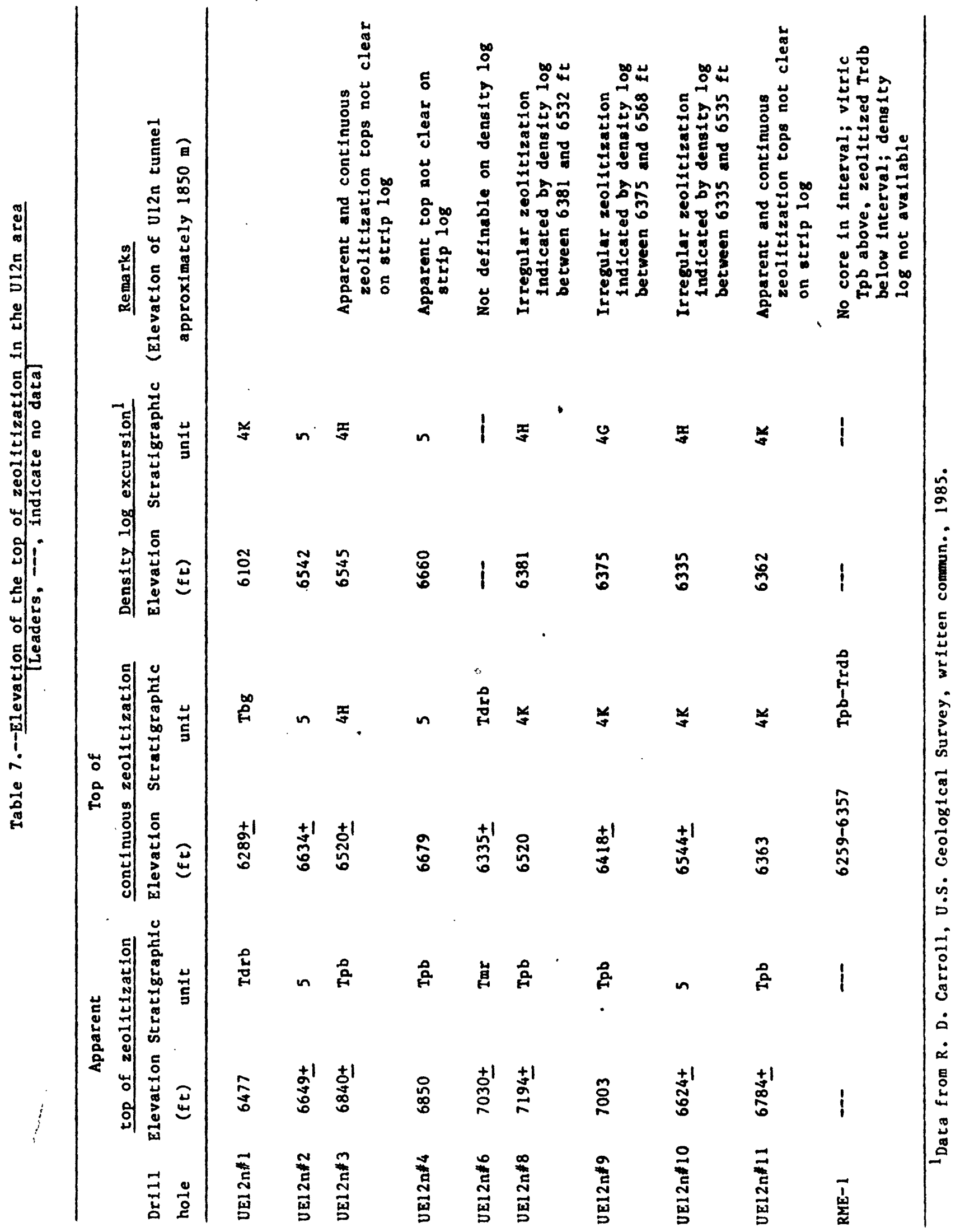




\section{Argillization}

Aryillized rocks, as defined by visible evidence in core, range from 1.3 to 10.3 percent of the stratigraphic units in tunnel beds $2-4$ (table $b$ ). Argillization was not observed in tunnel bed 5 . The stratigraphic relationship of increasing amounts of argillized rocks to the synclinal axis is apparent when data from vertical drill holes (samples are mostly on the northern slope of the syncline) are compared to samples from horizontal holes (samples are mostly near centę of syncline) (fig. 4C). When the data are separated into data from vertical holes (samples are mostly on the northern slope of the syncline) and data from horizontal holes (samples from younger units are closer to synclinal axis), the stratigraphic relationship of increasing amounts of argillized rocks to the synclinal axis is apparent (fig. 4D). Data from horizontal holes are from a limited stratigraphic interval. In horizontal holes, argillization of successively younger stratigraphic units is representative of aryillization in a cross section from the flank to the axis of the syncline. Intense aryillization of subunits $4 \mathrm{~J}$ and $4 \mathrm{~K}$ in the UIZn.U3 and n.US drill holes may somewhat exayyerate the relationship of aryillization and the syncline, but this relationship is clearly expressed in subunits $4 A-D$ through $4 H$ also (fig. $4 U$ ).

In addition to proximity to the synclinal axis, argillization is also related to litholoyy. Aryilization of ash-fall tuffs is slightly higher than can be accounted for by the ash-fall content of most stratigraphic subunits (fig. SA). Similarly, argillization of calc-alkaline ash-fall tuff is higher than can be accounted for by the calc-alkaline ash-fall tuffs of nearly all stratigraphic units (fig. 5B). These differences may be caused by differences in permeability or chemistry.

Argillization in the U12n.U3 drift (Ege and others, 1980) indicates a relationship to faults, the synclinal axis, and lithology. The U12n.03 drift crosses the synclinal axis at tunnel construction station (C.S.) 13+00 (pl. 2). Subunits $4 J$ and $4 K$ are present between C.S. $7+17$ and $18+69$ on either side of the axis. North- to north-northwest-trending faults are subparallel to the drift between C.S. U+00 and 17+U0. Argillization, defined by resistivities less than 20 ohm-meters (Ege and others, 1980), is present in subunits $4 \mathrm{~J}$ and 4K between C.S. $11+00$ and $18+00$. During construction, heaving ground that was caused by the weak, intensely argillized rock was encountered between $C . S$. $12+00$ and $17+00$. Although faults are as frequent and ash-fall tuff is nearly as abundant in subunits $4 \mathrm{G}$ and $4 \mathrm{H}$ as in units $4 \mathrm{~J}$ and $4 \mathrm{~K}$, intense argillization is present only in a few thin beds between C.S. $U+U O$ and $11+U 0$ in subunits $4 G$ and $4 \mathrm{H}$. The coincidence of the synclinal axis, faults, and abundant ash-fall tuff appears to control the location of intense aryillization in the U12n.03 drift.

Aryillization of subunits $4 \mathrm{~J}$ and $4 \mathrm{~K}$ in the U12n.05 main drift also indicates that the synclinal axis, abundant ash-fall tuffs, and faults control location of intense argillization (J.R. Eye and D.L. Hoover, U.S. Geological Survey, written commun., 1971). The U12n.U5 drift crosses the synclinal axis at C.S. $16+40$ (fig. 6). Subunits $4 \mathrm{~J}$ and $4 \mathrm{~K}$ are present between C.S. 9+97 and $22+35$ on either side of the axis. Intense argillization is present in subunits $4 \mathrm{~J}$ and $4 \mathrm{~K}$ and in subunit $4 \mathrm{H}$. Heaving ground that was caused by the weak, intensely argillized rock occurred between C.S. 9+00 and C.S. 21+00. Extensometer data, survey data, and drill hole data indicated that the 


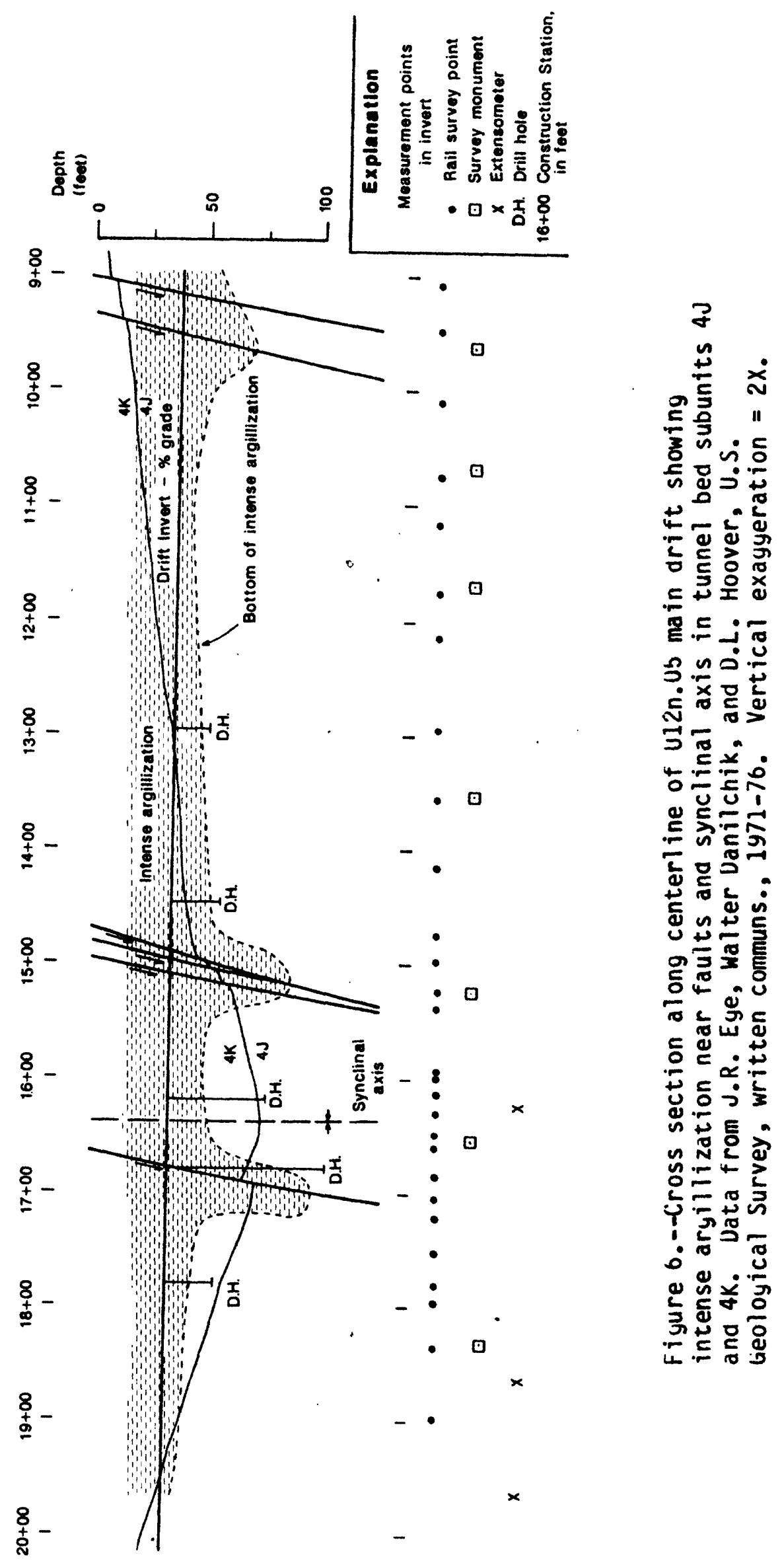


aryillized rock failed at depths of 10 to $40 \mathrm{ft}$ around the dritt (J.K. Ege, and U.L. Hoover, U.S. Geoloyical Survey, written commun., 1971). Intense aryillization was thickest near fault zones (fig. 6). X-ray analyses of samples trom elsewhere in the syncline indicate that intensely aryillized rocks, such as those in the UIZn.U3 and n.Us drifts, may contain more than 50 percent montmorillonite (R.D. Carroll, U.S. Geological Survey, written commun., 1986).

\section{Silicification}

Silicified rocks comprise $U$ to 7.1 percent of the rocks in the Ulin area (table $b)$. Although the stratigraphic distribution of all silicified rocks suygests an inverse relationship to the distribution of aryillized rocks (tig. 4C), stratigraphic distribution of silicified rocks in vertical and horizontal lioles indicates that this relationship does not exist (fig. 4D, E). With a few exceptions, tuffaceous sandstones are much more susceptible to silicification than other rocks (table 6 , fig. $5 \mathrm{C}$ ).

\section{MAP COMPILATION}

The UIZn area has been mapped at tunnel level by numerous yeoloyists of the U.S. Geulogical Survey and Fenix \& Scisson of Nevada from 1961 to 1 y8b. As each aritt or arill hole was completed, fault and stratigraphic contact strikes from adjacent dritts and drill holes were adjusted to fit the new data. The tunnel-level map ( $\mu 1$. 2) has been revised to provide consistency of map and drill-hole data throuyhout the $U 12 n$ area. The revisions are based on data in the U.S. Geoloyical Survey files as of May 1985. These data include unuublished and published reports and maps by Survey geologists and maps compiled by Fenix \& Scisson of Nevada, geologists for containment evaluation of arifts excavated since 1981.

The tunnel-level map $(p 1.2)$ is drawn on a sliyhtly undulating plane that tilts gently to the east. Undulations are present because arifts were constructed at yrades of 0.5 to 1.0 percent and were driven at various angles to the main drift and each other. The average yrade between the portal (elevation $1835.8 \mathrm{~m}$ ) and the U12n.10 WP (elevation $1850.7 \mathrm{~m}$ ), the WP furthest removed from the portal, is 0.72 percent. Only faults that cross two or more arifts or horizontal drill holes, have displacements greater than $1 \mathrm{ft}$, or are siyniticant to cunnel construction are shown on plate 2. Geologic mapping is at an elevation of $b$ tt above the floor of the tunnel.

The map on tup of the pre-volcanic rocks (p1. 3) shows structure contours, axes of paleotopoyraphy, and the major faults. The map was constructed trom arill-liole data and from fault data projected trom tunnel level. Construction of the map was begun in fault blocks where elevations of the pre-volcanic rocks were known from drill holes. Faults were projected frum tunnel level position and dip. Fault traces on the top of the prevulcanic rocks were constructed from intersections of contours on the prevolcanic rocks and contours on the fault planes. In fault blocks where only one arill-hole elevation was available or where elevations were not available, contours were constructed by the use of fault displacements and dips at tunnel level. 
Unly faults that cross the axis of the Rainier Mesa and Aqueduct Mesa synclines and that have a displacement of $10 \mathrm{ft}$ or more at one or more locations were projected to the pre-volcanic surface. Splays of the easternmost fault were projected because they are a part of the same fault in the area of the synclinal axis. The northeast-trending fault near the U12n.10 WP was included because gravity data indicated a significant displacement at the top of the pre-volcanic rocks (U.S. Geological Survey, 1979). Where fault dips were not available in drifts, dips were assumed. The assumed dip was based on dips measured elsewhere on the same fault. In a few locations, assumed dips were based on dips of faults with a similar displacement and orientation. Variable dips, strike changes, and high relief of the prevolcanic surface cause the irregular traces of faults on the pre-volcanic surface.

Contours are shown as smooth and mostly conformable with the stratiyraphic contacts at tunnel level. In outcrop, this smoothness and conformity are not always present in areas where the pre-volcanic rocks have high relief. Actual elevations more than $1,000 \mathrm{ft}$ away from drill holes may vary $7 \mathrm{~b}-3 \mathrm{UU} \mathrm{ft}$ from elevations interpreted from the contours.

The surface map (pl. 4) shows contacts, faults, and inferred faults on top of Rainier Mesa and on part of the eastern slope. Most of the U12n surface area was remapped at a scale of 1:12,000 (F.M. Byers, Jr., and R.P. Snyder, U.S. Geological Survey, written commun., 1973).

\section{STRUCTURE}

Pre-volcanic structures in the U12n area include Mesozoic folds and faults in Paleozoic rocks and the Gold Meadows stock. Structures in the volcanic rocks are normal faults and depositional folds that have been influenced by the pre-volcanic structures.

\section{Pre-volcanic Structures}

During Mesozoic time, Paleozoic eugeosynclinal and miogeosynclinal rocks were subjected to regional compressional deformation. In the U12n area, this deformation is expressed as the CP thrust fault (Barnes and Poole, 1968) and as a west- to northwest-trending right-lateral fault zone that can be extrapolated from east of the Ui2n area.

\section{CP Thrust Fault}

The CP thrust fault places the Stirling Quartzite and the Wood Canyon Formation of Precambrian and Cambrian aye over dolomite of Ordovician to Devonian age. The location of the edge of the thrust fault is inferred to be parallel to and near the synclinal axis in the tunnel beds and older volcanic rocks $(p l .1)$. On the north side of the syncline, several drill holes have penetrated quartzite or paleocolluvium that contains quartzite from the upper plate of the thrust fault. On the south side of the syncline, the U12b.07-2 drill hole penetrated dolomite in the lower plate at the base of the volcanic rocks. 


\section{Right-lateral Fault Zone}

Compressional deformation that caused the CP thrust fault also caused west- to northwest-trending riyht-lateral faults. These lateral faults have been found at several locations in the NTS area (Carr, 1974). Several lateral taults have also been noted in the Syncline Ridge area (Hoover and Morrison, 1980). The presence of a lateral fault beneath the UI2n area cannot be demonstrated, but can be inferred from two lines of evidence: (1) projection of a right-lateral fault zone east and southeast of Rainier Mesa, and (2) orientation of faults in volcanic rocks in the UI2n area.

The right-lateral fault zone is expressed by offset of pre-Tertiary contacts and structure. From east to west, these offset features are ( $p l .3)$ :

1. CP thrust fault in the Oak Spring quadrangle (Barnes and others, 1963).

2. Contact between subunits $G$ and $H$ of the Eleana Formation.

3. Easternmost contact of overturned beds in the Eleana Formation.

4. Subunit $E$ of the Eleana Formation within overturned beds.

5. Thrust fault of Ordovician to Devonian dolomitic limestone over the Eleana Formation.

b. Contact between subunits $B$ and $C$ of Devonian dolomite on the east side of Rainier Mesa.

The right-lateral offset of the CP thrust fault (1, pl. 3) in the Oak Spring quadrangle was interureted from drill-hole and gravity data (U.S. Geological Survey, 1974). The south side of the fault zone was interpreted to have 5UU $\mathrm{ft}$ of aisplacement down to the south at the base of the volcanic rocks. This fault was inferred between the area of investigation and the southernmost west-northwest-trending fault with lateral off set at the north end of the tleana Ranye. On the north side of the fault zone, the contact between subunits $G$ and $H$ is offset across the northernmost fault $(2, p) .3)$. Although the contact is not exposed on the north side of the fault, the contact on the south side of the fault is exposed and leaves little doubt as to the right lateral movement (Barnes and others, 1963).

A zone of overturned beds in the Eleana Formation is present in the Eleana Range and in outcrops north of the main wash that drains Rainier Mesa. The easternmost contact of these overturned beds is terminated at the south and north edges of the right lateral fault zone by west-northwesttrending faults (3, pl. 3). Similarly, subunit $E$ within the overturned beds is terminated $(4, \mathrm{pl} .3)$. Within the fault zone, outcrops indicate that several lateral faults differentially offset the overturned beds and unit $E$, but individual faults within the zone are concealed (Gibbons and others, 1963). Just west of the overturned beds, Ordovician to Devonian dolomitic limestone is thrust over the Eleana Formation south of the lateral fault zone $(5, \mathrm{pl}, 3)$. Within the lateral fault zone, the thrust fault is concealed by alluvium, but crops out north of the zone $(5, \mathrm{pl} .3)$. The northern outcrop and outcrops of Devonian limestone within the lateral fault zone leave little doubt as to the right-lateral offset within the zone. Two outcrops of the Antelope Valley Formation at the northwest corner of the Eleana Range (p1. 3) inaicate at least 2,000 ft of offset between the thrust fault south of the lateral fault zone and the southern side of the zone. 
The contact between units $B$ and $C$ of Devonian dolomite is also offset at least 2,000 ft laterally $(6, \mathrm{pl} .3)$. The fault is concealed beneath alluvium in the wash that begins just south of the U12n portal. North of the wash and the concealed fault, the contact of units $B$ and $C$ lies east of the outcrop of unit $C(6, \mathrm{pl}, 3)$. The right-lateral offset is therefore at least $1,300 \mathrm{ft}$. About 2,bU0 ft east of this outcrop of unit $C$, another outcrop of unit $C$ indicates the possibility of another right-lateral offset of $3,000 \mathrm{ft}$ or more (6, pl. 3).

Faults in volcanic rocks north and south of the U12n area have mostly N. $10^{\circ} \mathrm{W}$. to N. $20^{\circ} \mathrm{E}$. trends in contrast to mostly N. $20^{\circ}-40^{\circ} \mathrm{W}$. trends of faults in the UI2n area. The N. $10^{\circ} \mathrm{W}$. to N. $20^{\circ} \mathrm{E}$. trend is common in most volcanic rocks throughout the NTS area. Where Mesozoic right-lateral faults that have $E-W$ to $N$. $2 b^{\circ} \mathrm{W}$. trends are present, faults in volcanic rocks may parallel the older fault trends. In the Syncline Ridge area, about 7 miles southeast of Rainier Mesa, Mesozoic right-lateral faults with west-northwest trends were reactivated during Tertiary time along part of their length and offset the volcanic rocks north of Syncline Ridge and between Syncline Ridge and Mine Mountain (Hoover and Morrison, 198U). Presence of the right-lateral fault zone just east of the U12n area and the contrast between normal fault trends in volcanic rocks and fault trends in the U12n area strongly suggest the presence of a Mesozoic right-lateral fault zone beneath the U12n area. During late Tertiary time when the NTS area was subjected to $\mathrm{N} .50^{\circ} \mathrm{W}$. extension (Carr, 1974), the right-lateral fault zone would have provided preexisting planes of weakness. Vertical movement along these planes could account for the different orientation of faults in the U12n area.

\section{Gold Meadows Stock}

Intrusion of the quartz monzonite stock of Cretaceous age in Gold Meadows into the upper plate of the $C P$ thrust may have deformed the upper plate alony the north edge of Rainier Mesa and along the west side of. Aqueduct Mesa. This deformation may have influenced the location of the paleovalleys beneath the Rainier Mesa and Aqueduct synclines and the location of the divide between the paleovalleys of the two synclines $(p l, 1)$.

The effects of deformation by the intrusion on the possible right-lateral fault zone beneath the U12n area are uncertain. Faults with the greatest displacement in the volcanic rocks change strike from $\mathrm{N}$. $2 b-30^{\circ} \mathrm{W}$. south of the synclinal axis to $N$. $10^{0}-15^{\circ} \mathrm{W}$. north of the syncline. The change in strike may be caused by Mesozoic deformation of the lateral fault zone, by location of the upper plate on the north side of the syncline, by local stress changes caused by the intrusion, or some combination of these factors.

\section{Age of CP Thrust Fault and the Right-Lateral Fault Zone}

About 7 miles southeast of Rainier Mesa, the Tippipah Limestone of Pennsylvanian to Permian aye has been deformed by folding, thrust faults, and right-lateral faults that are contemporaneous with the $C P$ thrust and the lateral fault zone of the UI2n area. Therefore, the age of the CP thrust and the lateral fault zone are post-Tippipah Limestone. Intrusion of the upper plate of the CP thrust fault by the Gold Meadows quartz monzonite in the RME-1 drill hole and around the edge of the Gold Meadows stock establishes the age 
of the thrust fault as older than the Gold Meadows stock of Cretaceous age. Although the thrust faults and lateral fault zones in the Rainier Mesa and Syncline Ridge areas could be as old as Permian, Carr (1974) associates the right-lateral faults in the NTS area with the Walker Lane Belt shear zone. In the Walker Lane Belt, displacement of Jurassic plutons and depositional characteristics of Jurassic sediments indicate that movement may have begun after Middle Jurassic time (Carr, 1974).

\section{Structures in Volcanic Rocks}

Prior to deposition of the volcanic rocks, Precambrian through Mesozoic rocks were deeply eroded by two drainage systems in the U12n area. Deposition of volcanic rocks in the paleovalleys and their interfluves produced depositional folds. The volcanic rocks were deformed by normal faults, probably in two or more episodes of faulting after deposition of tunnel bed 4 .

\section{Depositional Folds}

Deposition in paleodrainaye systems in the pre-volcanic rocks has produced depositional folds in the volcanic rocks. The major folds in the U12n area are the Rainier Mesa and Aqueduct synclines. Source directions, faults, and possibly deformation related to the Timber Mountain or Silent Canyon calderas have affected the location of the synclinal axes within the volcanic rocks. Uips of the volcanic rocks decrease upward in the section. Thickness of stratigraphic units in the lower and upper parts of the volcanic rocks vary and may be dependent on erosion and position within the syncline or the direction and distance from depositional sources.

\section{Fold axes}

On top of the pre-volcanic rocks and at tunnel level, the Rainier Mesa and Aqueduct synclines are approximately coincidental. The two synclines are separated by a divide just east of construction station (C.S.) $13+00$ in the U12n.03 arift. The Rainier Mesa syncline plunges southwest and the Aqueduct syncline plunges northeast. At the surface, a single syncline plunges northeast roughly parallel to the subsurface axes of the two synclines, but offset $300-400 \mathrm{ft}$ to the south $(\mathrm{pl}, 2-4)$. The offset between the axial traces may be caused by yreater deposition of the Paintbrush Tuff on the north side of the syncline, erosional migration of the paleovalley prior to the deposition of the Rainier Mesa Member, or by uplift of the northern side of the syncline. West of the Ul2n drifts and drill holes, detailed mapping (pl. 4) indicates that the surface trace shown on the Rainier Mesa quadrangle (Gibbons and others, 1963) actually passes just south of the RME drill hole. Keconnaissance investiyations by the senior author indicates that the surface trace of the axis probably exits the west side of Rainier Mesa at approximately Nevada State coordinate N. 886,000.

West of the U12n area, the location of the synclinal axis is uncertain at the top of the pre-volcanic rocks. The axis is inferred to follow the trace of the $\mathrm{CP}$ thrust fault. This inference is based on the presence of the Stirling Quartzite and Wood Canyon Formation of the upuer plate in drill holes on the north side of the syncline and dolomite in the U12b.07-2 drill south of the axis. A similar relationship on Ayueduct Mesa is present in drill holes on either side of the axis of the Aqueduct syncline. Dips between the UE12n\#6 and RME-1 drill holes, approximately normal to the inferred axis, below tunnel bed $b$ (table 8 ) also suggest that the axis is near the RME-1 drili hole. 
Table 8.--Elevation of stratigraphic units in the UE12n\#6 and RME-1 drill holes, U12n area

\begin{tabular}{|c|c|c|c|}
\hline $\begin{array}{c}\text { Stratigraphic } \\
\text { Unit }\end{array}$ & \multicolumn{2}{|c|}{$\begin{array}{l}\text { Elevation of top of } \\
\text { stratiyraphic unit (feet) } \\
\frac{\text { UE12n } \$ 6}{\text { RME-1 }}\end{array}$} & $\begin{array}{l}\text { Difference in elevation } \\
\text { UEL } 2 n \# 6 \text { minus RME- } 1 \\
\text { (feet) }\end{array}$ \\
\hline $\begin{array}{c}\text { Rainier Mesa Member } \\
\text { (surface) }\end{array}$ & 7420 & 7367 & b3 \\
\hline Grouse Canyon Member & 6200 & $6263^{1}$ & -63 \\
\hline Tunnel bed $b$ & 6093 & $6179^{2}$ & -86 \\
\hline Tunnel bed 4 & 6010 & $5973-6062^{3}$ & 37 to -52 \\
\hline Tunnel bed 3 & 5699 & 5667 & 32 \\
\hline Tub Spring Member & 5498 & 5416 . & 82 \\
\hline Tutf of Yucca Flat & 5298 & 4732 & 566 \\
\hline
\end{tabular}

${ }^{1}$ Top of unit in uncored interval between 6260 and $6327 \mathrm{ft}$. Contact picked at excursion on gamma ray log.

${ }^{2}$ Top of unit in uncored interval between 6122 and $6250 \mathrm{ft}$. Contact picked at excursion on 3. yamma ray log.

3 Top of unit in uncored interval. 
Elevations of stratigraphic units in the UE12n\#6 and the RME-1 drill holes (table 8) indicate that the subsurface axial trace of the synclinal axis in tunnel bed 4 and older units is near the RME-1 drill hole, but that the axial trace is near UE12n\#6 in tunnel bed 5 and the Grouse Canyon Member. Units below tunnel bed 4 and the Rainier Mesa Member slope toward the RME-1 drill hole, but the top of tunnel bed $b$ and the Grouse Canyon Member slope toward UEl2n:6. The slope of the younger units may indicate a depositional, rather than an erosional, migration of the synclinal axis toward UE12n\#6. The source of tunnel bed $b$ and the lirouse Canyon Member, the Silent Canyon caldera, is a few miles west and northwest of RME-1. Decrease in thickness of tunnel bed $b$, an ash-fall tuff, away from the caldera may have been large enough that deposition caused southward migration of the synclinal axis.

Penetration of the lower plate of the CP thrust fault and the thick section of volcanic rocks in the RME-1 drill hole also suggest that the subsurtace axis of the Rainier Mesa syncline is just south of the drill hole. The RME-1 drill hole penetrated altered dolomite beneath quartz monzonite and quartzite intruded by pegmatite dikes. The presence of dolomite, rather than limestone that is present in the Stirling Quartzite and the Wood Canyon Formation, indicates that the lower plate of the CP thrust fault was penetrated. The $C P$ fault was not seen because of poor core recovery, but both the quartzite and dolomite were brecciated near the inferred fault. Volcanic rocks in the RME-1 drill hole are the thickest section in northern Rainier Mesa. Quarez monzonite in the U12r drill hole about 3,300 ft north of RME-1, is about $1,750 \mathrm{ft}$ higher than in RME-1. This elevation makes it unlikely that a major north-south paleovalley passes through RME-1.

West of the UIZn arifts, the location of the synclinal axis at tunnel level is uncertain, but several lines of evidence suggest that the subsurface traces approximate the surface trace. The axis of the syncline was not encountered in the UIZn extension drift $(\mu 1,2)$ and therefore must be north of that drift (U.K. Townsend, Fenix \& Scisson of Nevada, oral commun., 1985). In the U12n area, drill-hole data indicate that the axial traces at tunnel level and on top of the pre-volcanic rocks approximate the trace of the CP thrust fault on top of the pre-volcanic rocks.

\section{Dijs and thickness of volcanic rocks}

The northern paleovalley slope of the Rainier Mesa syncline averayes $14^{\circ}$ and relief is about $2,400 \mathrm{ft}$ from the closest peak of the Gold Meadows stock to the bottom of the Rainier Mesa paleovalley. Averaye paleovalley slopes from the northern edge of Rainier Mesa range from $25^{\circ}$ to $29^{\circ}$ between UE12n\#2, $n \# 3, n \# 8$, and $n \# y$ drill holes and the paleovalley axis. The average slope from UE12n:10 is about 19030', and from UE12n*11, less than $9^{\circ} 30^{\prime}$ to the paleovalley axis. The lower slopes and greater thickness of paleocolluvium in the last two holes and the location of these drill holes just west of and on the downthrown side of a large fault strongly suggest the presence of a tributary to the Rainier Mesa synclinal valley along the fault trace. The convexity of the northern paleovalley slope in the U12n.10 area toward the synclinal axis suggests that intrusion of the Gold Meadows stock may have deformed the upper plate of the CP thrust. Sparse elevations at the base of the volcanic rocks indicate that paleovalley slopes range from $4^{\circ}-12^{\circ} 30^{\prime}$ on the south side of the Rainier Mesa syncline. 
Vepositional folds in the U12b tunnel area at the south edge of the U12n area indicate that fold axes of tributaries on the south side of the Rainier Mesa syncline are subparallel to the axis. Depositional folds between the U12n portal and C.S. $25+U U$ indicate that tributaries are subparallel to the Aqueduct paleovalley. The axis of a syncline just east of the U12n portal can be traced for at least two miles parallel to the Aqueduct syncline (Gibbons and others, 1963).

Stratigraphic units of the volcanic rocks might be expected to be greater in thickness and the amount of reworked ash-fall tuff and tuffaceous sandstone in the center of the syncline than on the flanks because of greater deposition in the center and.greater erosion on the flanks. Comparison of unfaulted stratigraphic units in UElZn\#l, near the synclinal axis, and UE $12 n \# 3$, highest on the north flanks of the syncline, does not indicate a consistent thickeniny or yreater amount of reworked ash-fall tuff and tuffaceous sandstone within individual stratigraphic subunits of the tunnel beds but aggregate thickness and amount of reworked ash-fall tuff and tuffaceous sandstone is greater in the center of the syncline (table 9).

Part or all of the difference in tunnel beds $3-b$ could be ascribed to different sources at various distances, but the thicknesses of the Paintbrush Tuff and the Rainier Mesa Member of the Timber Mountain Tuff (table 9) indicate that deposition was yreater in the center. Data on units between the Tub Spring Member of the Belted Range Tuff and the pre-volcanic rocks are sparse, but $190 \mathrm{ft}$ of section below tunnel bed 3 in UE12n\#3, as compared to $1,646 \mathrm{ft}$ in the RME-1 drill hole near the center of the syncline and the absence of some of the older ash-flow tuffs on the synclinal flanks, also indicate erosion on the flanks and yreater deposition in the center of the syncline.

Depositional folds have been maintained during deposition of the volcanic rocks, but dips are yenerally less in younger stratigraphic units, particularly on the flanks of the Rainier Mesa syncline (table 10). Most of the change in dip occurs between tunnel bed 1 and younger units.

At tunnel level where control points are dense, contacts of stratigraphic units in tunnel beds $2-4$ are relatively smooth and thicknesses change gradually. Structure contours on the paleovalley slopes (pl. 3) reflect the smoothness of contacts at tunnel level, but control points are sparse and the paleovalley slopes may have relief not indicated by the contours. Thicknesses of units below tunnel bed 2 range from $2 \mathrm{ft}$ in UEl2n\#2 on the west to $276 . b \mathrm{ft}$ in UE12n\#11 on the east (Maldonado and others, 1979). The variation in thickness, approximately along the structure contours, suggests more relief than the contours indicate, but data on the elevation of the paleovalley slopes is too sparse to indicate such relief.

\section{Faults}

At tunnel level, several faults extend across the U12n area and have displacements of $6-12 b \mathrm{tt}$ down to the west (p1. 2). Between these longer faults, shorter faults with displacements of $2-25 \mathrm{ft}$ join the longer faults at acute anyles. Most of the shorter faults are displaced down to the west. Dips on the lonyer faults mostly range from $65^{\circ}$ to $85^{\circ}$, but locally dips are $b b^{\circ}$ to $6 b^{\circ}$. Dips on the shorter faults mostly range from $60^{\circ}$ to $80^{\circ}$, but a few faults have dips as low as $40^{\circ}$ and as large as $86^{\circ}$. 
Iavle y.--Comparison of total thickness and percent of reworked ash-tall tutt

and tuffaceous sandstone in stratigraphic subunits, UtI 2 n\# 1 and UE12n\#3.

\begin{tabular}{|c|c|c|c|c|}
\hline \multirow[b]{2}{*}{$\begin{array}{l}\text { Stratigraphic } \\
\text { subunit }\end{array}$} & UE1 $2 n \# 1$ & & \multicolumn{2}{|c|}{ UE1 $2 n \# 3$} \\
\hline & $\begin{array}{c}\text { Thickness } \\
(\mathrm{m})\end{array}$ & $\begin{array}{l}\text { Reworked ash-fall } \\
\text { tutf and tutfaceous } \\
\text { sandstone (percent) }\end{array}$ & $\begin{array}{l}\text { Thickness } \\
(\mathrm{m})\end{array}$ & $\begin{array}{l}\text { Reworked ash-fall } \\
\text { tuff and tuffaceous } \\
\text { sandstone (percent) }\end{array}$ \\
\hline $\begin{array}{l}3 A \\
3 B C \\
4 G \\
4 H \\
4 J \\
4 K-51\end{array}$ & $\begin{array}{r}7.9 \\
41.1 \\
6.7 \\
10.7 \\
22.6 \\
61.6\end{array}$ & $\begin{array}{r}u . u \\
33.3 \\
9.1 \\
14.3 \\
8.1 \\
22.3\end{array}$ & $\begin{array}{r}3.2 \\
23.2 \\
4.9 \\
14.3 \\
14.6 \\
69.8\end{array}$ & $\begin{array}{r}0.0 \\
34.2 \\
18.8 \\
23.4 \\
2.1 \\
12.2\end{array}$ \\
\hline All tunnel beds & s $1 b 0.6$ & 20.9 & 132.0 & 16.9 \\
\hline $\begin{array}{l}T p b^{2} \\
T m r\end{array}$ & $\begin{array}{r}245.5 \\
93.3\end{array}$ & & $\begin{array}{r}199.0 \\
41.5\end{array}$ & \\
\hline
\end{tabular}

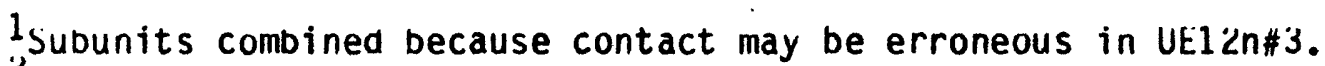

'Includes curfs of Area 20 and of Uead Horse Flat and Stockade Wash Tutf. 


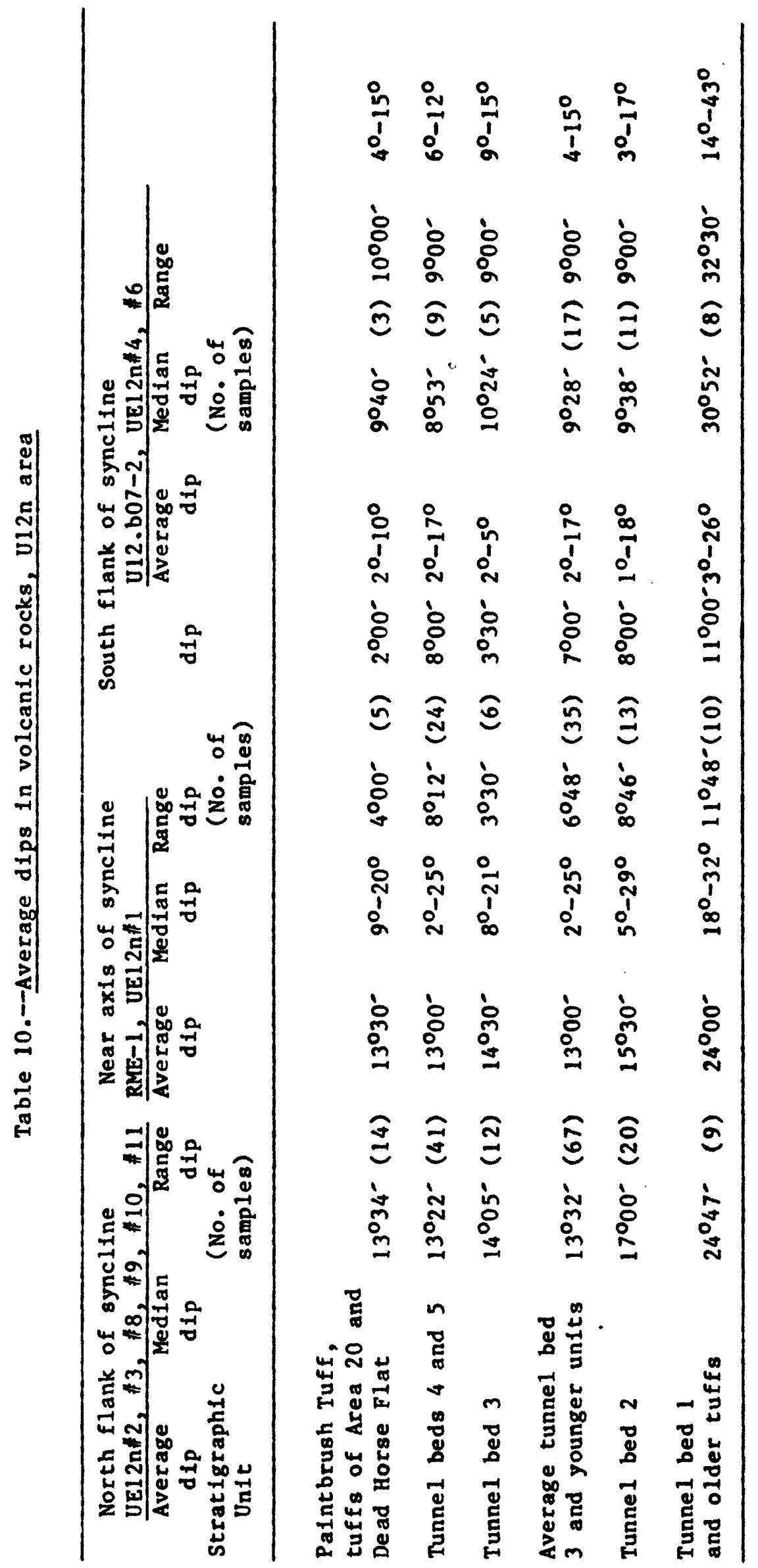


The orientation of the longer faults ranges from $\mathrm{N} .13^{\circ} \mathrm{W}$. to $\mathrm{N} .52^{0} \mathrm{~W}$., but most of the faults have a $\mathrm{N}_{0} 15^{0}-30^{0} \mathrm{~W}$. strike. The north-northwest strike in the U12n area and in volcanic rocks at the surface around the U12n portal contrast with north-south to north-northeast strikes in areas south and northeast of the U12n area. A scarp in pre-volcanic rocks with $100-2 b U$ ft of: offset was interpreted from yravity and drill hole data in the U12n.10 area (U.S. Geoloyical Survey, 1979). This fault scarp, buried by volcanic rocks, has a northeast trend subparallel to faults at tunnel level. The northwest strikes in the UIZn area may be caused by reactivation during Tertiary time of the pre-volcanic right-lateral fault zone. The northwest-southeast direction of extension that began about $10 \mathrm{~m} . \mathrm{y}$. ago should not produce vertical movement on northwest-trending faults (Carr, 1974), but local stress variations may have caused reactivation of this fault zone.

Orientation of the shorter faults ranyes from $N_{0} 50^{\circ} \mathrm{W}$. to $\mathrm{N}_{0}: 45^{\circ} \mathrm{E}$., but most faults have strikes between $N .10^{\circ} \mathrm{W}$. and $\mathrm{N} .40^{\circ} \mathrm{W}$. Some of the shorter faults appear to be subparallel splays of the longer faults, but most join the lonyer faults at large acute angles or are isolated from the longer faults. Most of the shorter faults may be the result of failure within blocks between longer faults, and thus, may be only indirectly related to reactivation of faults in the pre-volcanic fault zone. Northeast-trending faults near the end of the U12n.10 drift may be caused by Tertiary reactivation of faults in prevolcanic rocks with similar strikes.

Exposures of fault planes in the U12n drifts have slickensides that indicate the last movement on these faults was downdip or at a small angle to the dip. Most faults contain less than half an inch of gouge. Faults with displacements yreater than $15 \mathrm{ft}$ may have fractures or small faults subparallel to the main fault in a zone that is rarely more than $3 \mathrm{ft}$ wide. Fault breccia usually occurs only in the strongest rocks, such as well-sorted, zeolitized reworked ash-fall tutf or silicified, tuffaceous sandstones. Cavities in fault breccias usually have a maximum dimension less than $1 \mathrm{ft}$. Cavities along fractures in silicified tuffaceous sandstones have been found next to taults. The cavities are irregular and usually have a inaximum dimension less than $U .4 \mathrm{tt}$. Near the end of the U12n.U6 drift, cavities in a tutfaceous sandstone next to the large fault at C.S. $20+45$ contained viscous silica gel. The silica yel in the cavities sugyests that these cavities may be caused by dissolution of silica in the tuffaceous sandstone.

Some of the longer faults at tunnel level extend to the surface (p)s. 2, 4, b). The trace of the surface faults across steep slopes along the Aqueduct surface arainage indicates that the faults are very near vertical at the surface. The surface traces are northeast of the traces at tunnel level. The near vertical dips and the offset location at the surface requires an increase in dip between the tunnel level and surface. The increase may be gradual because of changes in stress with depth, the increase may occur at discontinuities of physical properties such as near the base of the Rainier Mesa Member and at the top of the zeolitized tuffs, or more probably, the dips may increase for both reasons. 
Shorter faults may be lacking at the surface for two reasons:

1. They intersect the longer faults below the surface.

2. Smaller displacements are absorbed by the weak, vitric bedded tuff of the Paintbrush Tuff.

A third reason may be that the small displacements of the shorter faults are concealed at the surface, but detailed mapping (F.M. Byers, and R.P. Snyder, U.S. Geological Survey, written commun., 1976) and large exposures of bedrock indicate this reason is unlikely. On Rainier Mesa and Pahute Mesa, fewer faults are present in vitric bedded tuffs than in more competent rocks adjacent to them.

Compaction faults, caused by overburden weight, in vitric bedded tuffs of the Paintbrush Tuff exposed on Rainier and Pahute Mesas have displacements of 6 in to $3 \mathrm{ft}$ that die out within $15-30 \mathrm{ft}$ of the maximum displacement. This die-out of compaction faults suggests a similar termination of the shorter faults that occur in the tunnel beds. 


\section{REFERENCES CITED}

Barnes, Harley, and Poole, F.G., 1968, Regional thrust-fault system in Nevada Test Site and vicinity in Eckel, E.B., ed., Nevada Test Site: Geological Society of America Memoir 110, p. 233-238.

Barnes, Harley, Houser, F.N., and Poole, F.G., 1963, Geology of the Oak Spring quadrangle, Nye County, Nevada: U.S. Geological Survey Geologic Quadrangle Map GU-214, scale 1:24, UUU.

Byers, F.M., Jr., Carr, W.J., Orkild, P.P., Quinlivan, W.U., and Sargent, K.A., 1976, Volcanic suites and related cauldrons of Timber Mountain-0asis Valley caldera complex, southern Nevada: U.S. Geological Survey Professional Paper 919, $70 \mathrm{p}$.

Carr, W.J., 1974, Summary of tectonic and structural evidence for stress orientation at the Nevada Test Site: U.S. Geological Survey Open-File Report 74-176, 33 p.

Carr, W.J., Byers, F.M., Jr., and Orkild, P.P., 1986, Stratigraphic and volcano-tectonic relations of Crater Flat Tuff and some older volcanic units, Nye County, Nevada: U.S. Geological Survey Professional Paper 1323, $28 \mathrm{p}$.

Dixon, G.L., Sargent, K.A., and Carr, W.J., 1976, Abandonment of the Indian Trail Formation and distribution of certain equivalent ash-flow tuffs, eastern Nevada Test Site: U.S. Geoloyical Survey Bulletin 1422-A, P. A49A54.

Eye, J.R., Carroll, R.D., Mayner, J.E., and Cunningham, D.R., 1980, U.S. Geoloyical Survey investiyations in the U12n.U3 $\mathrm{drift}$, Rainier Mesa, Area 12. Nevada Test Site: U.S. Geological Survey Upen-File Report 8U-1074, 29 p.

Ege, J.K., Uanilchik, Walter, and Feazel, J.T., 1980, leoloyy of the U12n.02 (Midi Mist) drift, and postshot observations, Rainier Mesa, Area 12, Nevada Test Site: U.S. Geological Survey Keport USGS-474-229, 21 p.; available only from U.S. Uepartment of Comnerce, National Technical Information Service, Springfield, VA 22161.

tkren, E.B., Anderson, R.E., Royers, C.L., and Noble, U.C., 1971, Geology of northern Nellis Air Force Base Bombing and Gunnery Range, Nye County, Nevada: U.S. Geoloyical Survey Professional Paper $6 b 1,91 \mathrm{p}$.

Ellis, W.L., and Kibler, J.D., 1983, Explosion-induced stress changes estimated from vibratiny-wire stressmeter measurements near the Mighty Epic event, Nevada Test Site: U.S. Geological Survey Open-File Report 83-642, $2 b \mathrm{p}$.

Ellis, W.L., and Magner, J.E., 1980, Compilation of results of threedimensional stress determinations made in Rainier and Aqueduct Mesas, Nevada Test Site: U.S. Geological Survey Open-File Report 80-1098, 27 p.

Gibbons, A.B., Hinrichs, E.N., Hansen, W.R., and Lemke, R.W., 1963, Geol ogy of the Rainier Mesa quadrangle, Nye County, Nevada: U.S. Geological Survey Geoloyic Quadrangle Map GQ-215, scale $1: 24,000$.

Hansen, W.R., and Lemke, R.W., 1958, Geology of the USGS and Rainier Mesa Tunnel areas, Nevada Test Site: U.S. Geological Survey Trace Elements Investiyations Report 716 (U.S. Geoloyical Survey Open-File Report 59-48), $111 \mathrm{p}$.

Healey, D.L., and Miller, C.H., 1963, Gravity survey of the Gold Meadows stock, Nevada Test Site, Nye County, Nevada, in Short papers in geology and hydroloyy: U.S. Geoloyical Survey Professional Paper 475-B, p. B64-66. 
Hinrichs, E.N., and Orkild, P.P., 1961, Eight members of the Oak Spring Formation, Nevada Test Site and vicinity, Nye and Lincoln Counties, Nevada, in Short papers in the geologic and hydrologic sciences: U.S. Geological Survey Professional Paper 424-D, P. Dy6-D9y.

Hoover, D.L., 1968, Genesis of zeolites, Nevada Test Site, in Ecke1, E.B., ed., Nevada Test Site: Geological Society of America Memoir 110, p. 27b284.

Hoover, U.L., and Morrison, J.N., 1y8U, Geology of the Syncline Ridye area related to nuclear waste disposal, Nevada Test Site, Nye County, Nevada: U.S. Geoloyical Survey Upen-File Report 80-942, 70 p.

Johnson, M.S., and Hibbard, U.E., 1957, Geology of the Atomic Eneryy Commission Nevada Proving Grounds area, Nevada: U.S. Geological Survey Bulletin 1U21-K, p. 333-384.

Maldonado, Florian, Steele, S.G., and Townsend, D.K., 1979, Supplementary litholoyic logs of selected vertical drill holes in Area 12, Nevada Test Si te: U.S. Geological Survey Report USGS-474-261, 61 p.; available only from U.S. Department of Commerce, National Technical Information Service, Springfield, VA 22161.

Marvin, R.F., Byers, F.M., Jr., Mehnert, H.H., Orkild, P.P., and Stern, T.W., 1970, Radiometric ages and stratigraphic sequence of volcanic and plutonic rocks, southern Nye and western Lincoln Counties, Nevada: Geological

Society of America Bulletin, v. 81, p. 2657-2676.

Naeser, C.W., and Maldonado, Florian, 1981, Fission-track dating of the Climax and Gold Meadows stocks, Nye County, Nevada, in Short Contributions to Geochronoloyy: U.S. Geological Survey Professional Paper 1199-E, P. 4b-47 (supersedes Open-File Report 78-419).

Nolan, T.B., 1929, Notes on the stratigraphy and structure of the northwest portion of Spring Mountain, Nevada: American Journal of Science, v. 17, $p$. 461-72.

Urkild, P.P., 196b, Paintbrush Tuft and Timber Mountain Tuff of Nye County, Nevada, in Cohee, G.V., and West, W.S., Changes in stratigraphic nomenclature by the U.S. Geological Survey, 1964: U.S. Geoloyical Survey Bullet in 1224-A, p. A44-Ab1.

Orkild, P.P., Saryent, K.A., and Snyder, R.P., 1969, Geologic map of Pahute Mesa, Nevada Test Site and vicinity, Nye County, Nevada: U.S. Geological Survey Miscellaneous Investigations Map 1-b67, scale 1:48,000.

roole, F.G., and Mckeown, F.A., 1962, Oak Spring Group of the Nevada Test Site and vicinity, in Short papers in geology and hyarology: U.S. Geological Survey Professional Paper 4bU-C, $\mu . \mathrm{CbO}-\mathrm{Cb2}$.

Saryent, K.A., Noble, D.C., and Ekren, E.B., 196b, Belted Ranye Tuff of Nye and Lincoln Counties, Nevada, in Cohee, G.V., and West, W.S., Changes in stratiyraphic nomenclature, 1964: U.S. Geoloyical Survey Bulletin 12'24-A, N. A32-A36.

Snyder, R.P., 1977, Geoloyy of the Gold Meadows stock, Nevada Test Site: U.S. Geoloyical Survey Report USGS $-474-179,13$ p.; available only from U.S. Department of Commerce, National Technical Information Service, Springfield, VA 22161.

U.S. Geological Survey, 1974, Results of exploration of Baneberry site, early 1971: U.S. Geological Survey Report USGS-474-14b, 94 p.; available only from U.S. Department of Commerce, National Technical Information Service, Springfield, VA 22161.

U.S. Geological Survey, 197y, U.S. Geological Survey investigations in connection with the Mighty Epic event, U12n.10 tunnel, Nevada Test Site: U.S. Geological Survey Report USGS-474-228, 191 p.; available only from U.S. Department of Commerce, National Technical Information Service, springfield, VA 22161. 